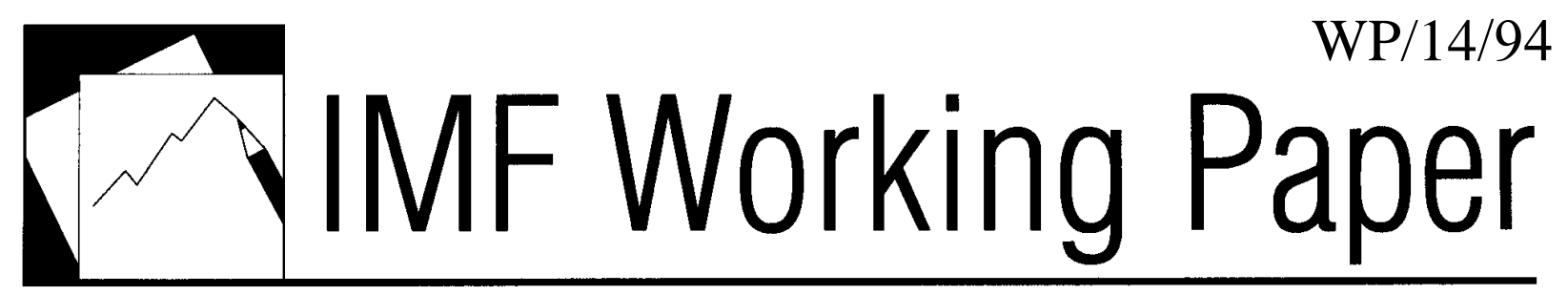

\title{
Does Openness Matter for Financial Development in Africa?
}

Antonio C. David, Montfort Mlachila, and Ashwin Moheeput 


\title{
IMF Working Paper
}

\author{
African Department
}

\section{Does Openness Matter for Financial Development in Africa? ${ }^{1}$}

\section{Prepared by Antonio C. David, Montfort Mlachila and Ashwin Moheeput}

\author{
Authorized for distribution by Alfredo Cuevas
}

June 2014

\begin{abstract}
This Working Paper should not be reported as representing the views of the IMF.
The views expressed in this Working Paper are those of the author(s) and do not necessarily represent those of the IMF or IMF policy. Working Papers describe research in progress by the author(s) and are published to elicit comments and to further debate.
\end{abstract}

\begin{abstract}
This paper analyzes the links between financial and trade openness and financial development in SubSaharan African (SSA) countries. It is based on a panel dataset using methods that tackle slope heterogeneity, cross-sectional dependence and non-stationarity, important econometric problems that are often ignored in the literature. The results do not point to a general direct robust link between trade and capital account openness and financial development in SSA, once we control for other factors such as GDP per capita and inflation. But there is some indication that trade openness is more important for financial development in countries with better institutional quality. The findings might be due to a number of factors including distortions in domestic financial markets, relatively weak institutions and/or poor financial sector supervision. Thus, African policy makers should be cautious about expectations regarding immediate gains for financial development from greater international integration. Such gains are more likely to occur through indirect channels.
\end{abstract}

JEL Classification Numbers: F36, F43, O16

Keywords: Financial Development, Trade Openness, International Financial Integration, sub-Saharan Africa

Authors ‘E-Mail Address: ADavid@imf.org; MMlachila@imf.org; AMoheeput@imf.org

\footnotetext{
${ }^{1}$ The authors are grateful to Calixte Ahokpossi, Ari Aisen, Alfredo Cuevas, Domenico Fanizza, Tidiane Kinda, Youssouf Kiendrebeogo, Yibin Mu, Magnus Saxegaard, and participants at the African Department's Financial Sector Network seminar in which this paper was presented, for comments and suggestions, and to David Corvino for excellent research assistance. The usual caveats apply.
} 


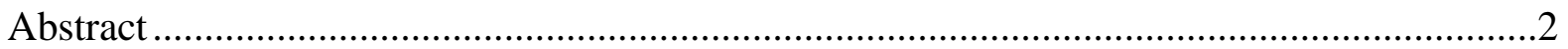

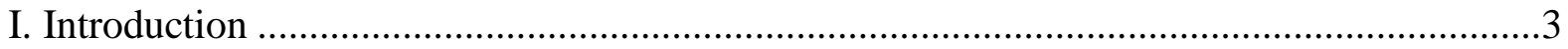

II. Openness and Financial Development-An Overview of the Literature ..........................5

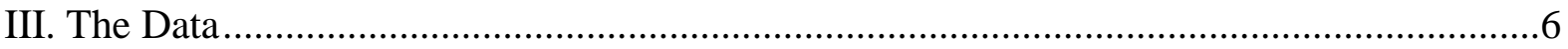

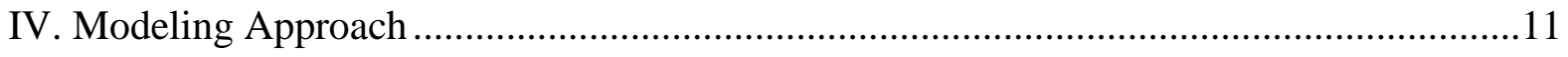

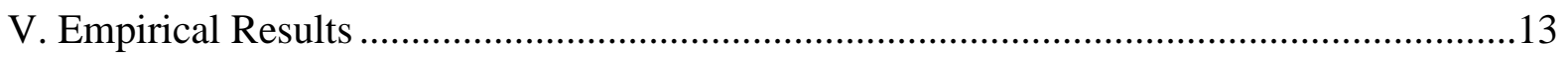

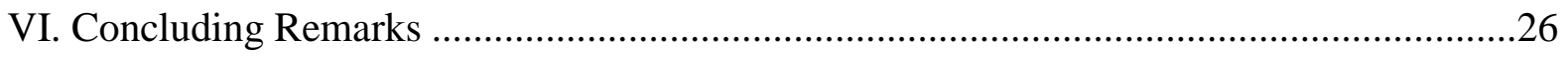

Tables

1. Estimation Results for Variables in Levels ...................................................................15

2. Estimation Results for Variables in First Differences ..................................................... 17

3. Estimation Results over Period 1982-1995 ....................................................................19

4. Estimation Results Including Financial Reforms ...................................................21

5. Robustness Checks: Additional Regressors ...........................................................26

Figures

1. SSA Composite Financial Development Index ....................................................... 3

2. Financial Sector Development Indices for Selected Regions .........................................

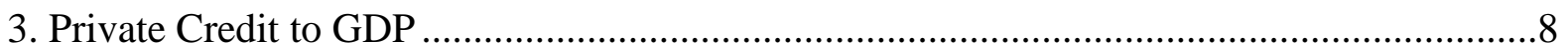

4. Financial Reform Index ......................................................................................... 10

5. Sub-Saharan Africa: Scatter Plots of the Relationships between Financial Development and Measures of Openness ....................................................................................... 11

6. Country-specific Coefficients, Institutional Quality and Development Indicators (Levels) 23

7. Country-specific Coefficients and Institutional Quality (First Differences) .....................24

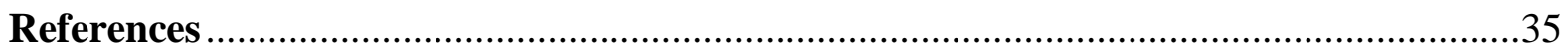

Annexes

Annex A: List of Countries Included in the Regressions ...............................................29

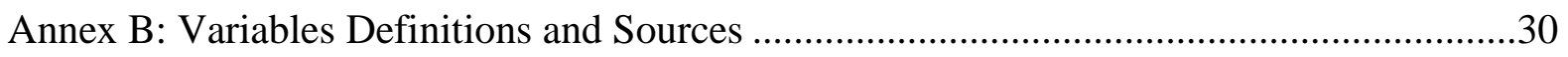

Annex C: Descriptive Statistics for Selected Variables........................................................31

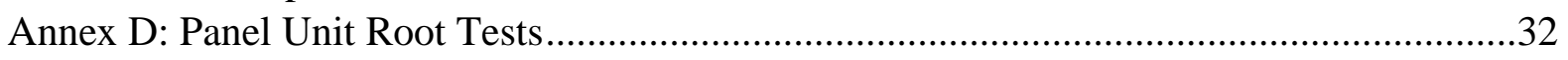

Annex E: Robustness Checks: Chinn-Ito (2006) regressions ..............................................33

Annex F: Robustness Checks: GMM Estimators ............................................................34 


\section{INTRODUCTION}

Despite reforms, Sub-Saharan Africa (SSA) continues to lag behind other regions in terms of financial development. At least by one measure - private sector credit-to-GDP ratio-SSA countries are barely catching up to levels attained in the early 1980s. In fact, the financial sectors of most countries in SSA still remain among the shallowest in the world and, within SSA, they are shallower in the CFA franc zone. ${ }^{2}$

A number of factors have been proposed to explain this relative backwardness. Singh, Kpodar and Ghura (2009) show that differences in institutional quality can to a large extent explain cross-country differences in financial development in the region. Beck and Honohan (2007) stress the role of informality, lack of scale in national financial systems, weak governance, and political and economic instability in explaining the lack of financial development in SSA. Allen and others (2012) argue that the sparse population density of many SSA countries appears to be the main reason underlying the relative underdevelopment of financial systems.

Over the past four decades, financial sector development in SSA has been uneven and suffered reversals at certain times. There was relatively rapid financial deepening during most of the 1970 s, a period of relatively high economic growth. During most of the 1980 s, the "lost decade", there was stagnation, and even reversal of the gains from the 1970s, especially during the early 1990s. This trend was reversed from the latter period through the 2000s. Indeed, there has been an acceleration in financial development especially from 2006 (Figure 1).
Figure 1. SSA: Composite Financial Development Index SSA: Composite Financial Development Index

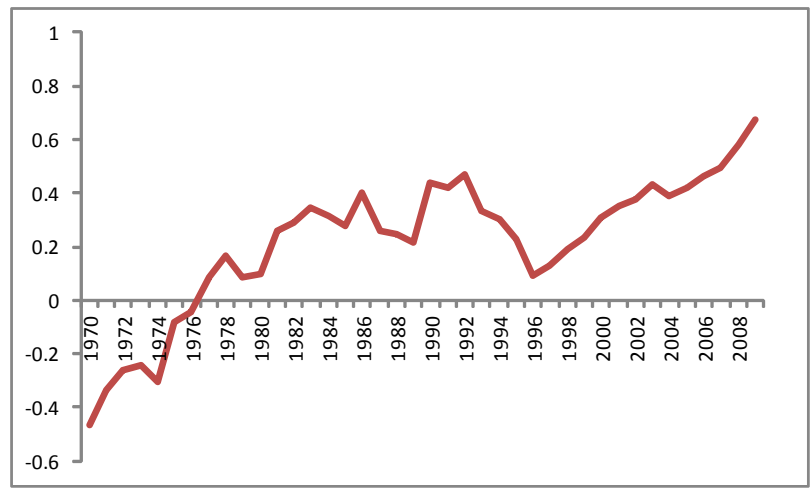

This paper aims at exploring the reasons that could explain these trends in SSA. In a seminal paper, Rajan and Zingales (2003) put forward a hypothesis that trade and financial openness are a necessary condition for genuine financial development. They argue that just developing "institutions" without greater integration into the rest of the world, is inadequate to foster

\footnotetext{
${ }^{2}$ This includes the Western African Economic and Monetary Union (WAEMU) and the Central African Economic and Monetary Community (CEMAC) countries. Features such as limited financial products and instruments, relatively few bank branches, high interest rate spreads, weak legal systems, poor governance of banks and improper risk management techniques, continue to characterize the financial sectors of most CFA franc zone countries.
} 
financial development due to political economy considerations. Their argument is based on the observation that a country's dominant economic incumbents see financial sector development as a threat and would act against it. Only if borders are open to both trade and capital flows are countries likely to see the opposition to financial development most muted, and development flourish, because more firms are able to benefit from the opening.

Our paper is inspired by the Rajan and Zingales hypothesis and empirical work done by Baltagi, Demetriades and Law (2009), but has a focus on African economies where there are relatively few studies from this perspective. Using a panel of 34 SSA countries covering a long period-1970-2009 — we use dynamic panel techniques to quantify the importance of financial and trade openness for financial development controlling for other institutional and macroeconomic factors.

We believe that there is scope to reexamine the links between openness and financial development for several reasons. Firstly, other studies typically consider only a small set of SSA countries. Furthermore, those empirical papers that have examined the links between financial development and openness with panel data usually employed econometric techniques that impose homogeneity of slope coefficients across countries - an assumption that is likely to be violated given the heterogeneity of economies in SSA. In addition, the empirical models estimated frequently restrict dynamics by considering non-overlapping five year periods (Chinn and Ito, 2006) or even only two time periods (Klein and Olivei, 2008).

Our results suggest that in general there is no direct and robust link between openness and financial development in SSA when other factors are controlled for. But there are some indications that trade openness is more important for financial development in countries with better institutional quality. These conclusions differ from the findings of a number of other authors for a broader sample of countries. Differences may partly be a reflection of different sample of countries and periods, and econometric techniques used, but there might also be important economic and structural explanations that would prevent the realization of potential gains from further international integration. These might include the presence of weaker institutional frameworks, significant distortions in domestic financial markets, and/or inadequate financial supervision capacity.

The rest of the paper is organized as follows: Section II provides an overview of the literature on the links between financial development, trade and capital account openness. Section III presents the data and Section IV the modeling approach adopted in the paper. Section V presents the regression results and a number of robustness checks. Finally, Section VI concludes. 


\section{OPENNESS AND FinANCIAL DEVELOPMENT-An OVERVIEW OF THE Literature}

\section{Mechanisms Linking Openness and Financial Development}

Perhaps the most direct channel through which openness would affect financial development is through increases in the size of markets and demand for financial services. In this context, increased trade openness generates demand for new financial products, including instruments for trade finance and for hedging of risks (Svaleryd and Vlachos, 2002). In addition, capital account openness might increase liquidity and reduce the cost of capital, hence fostering financial development. Levine (2001) provides some evidence that abolishing restrictions on international portfolio flows tends to increase stock market liquidity.

Political economy factors are also thought to be an important channel. Rajan and Zingales (2003) argue that special interest groups (incumbents) oppose financial development because the ensuing greater competition erodes their rents, given that these groups can finance themselves with retained profits whereas potential competitors need external finance to begin operations. These authors argue that simultaneous opening of the trade and capital accounts is capable of weakening the incumbents' powers to block financial development and might even generate sufficient new profits so as to outweigh the negative effects of increased competition on incumbents and thus reduce opposition to reform.

Moreover, a number of authors have pointed to a possible link between greater trade and capital account openness and stronger institutions and/or better policies, which would promote financial development. Mishkin (2009) argues that the entry of foreign capital fosters a type of "technology transfer", prompting domestic banks to upgrade their lending standards and follow international best practices. Kose and others (2009) argue that capital account liberalization might impose discipline on macroeconomic policies by increasing the benefits of appropriate policies, while also increasing the costs of inadequate ones. These authors point to some empirical evidence that suggest that countries with higher financial openness are more likely to have better monetary policy outcomes, although there is no evidence of a "disciplining effect" of openness on fiscal policy.

Nevertheless, it is important to note that while openness can foster financial development through numerous channels, it may also bring in increased volatility stemming from greater likelihood of financial crises (Kose and others, 2009). Openness in the absence of appropriate macro-prudential measures and financial stability safeguards such as financial sector regulation/supervision, might lead to excessive risk taking.

\section{Previous Empirical Results}

We will briefly review the empirical literature on the links between openness and financial development in this section, while leaving a more detailed discussion of how our results 
relate to the literature to subsequent sections. Baltagi, Demetriades and Law (2009) test the Rajan and Zingales hypothesis through dynamic panel techniques for a broad sample of countries. They provide evidence that trade and capital account openness are important determinants of banking sector development and conclude that although opening up both the trade and capital accounts is more beneficial; opening one without the other also fosters financial development. Klein and Olivei (2008) also find that capital account liberalization is linked to greater financial sector depth in a sample of advanced and developing economies.

Nevertheless, Chin and Ito (2006) show that, in a panel of 108 countries over the period 1980 to 2000, higher levels of financial openness only lead to financial sector development if a threshold of legal development has been attained. Gries, Kraft and Meierrieks (2009) look at the links between financial deepening, trade openness, and economic development for a sample of 16 African countries using time series techniques. They find that the links between financial development and trade openness are not very robust, with results varying significantly by country, despite concluding that there is evidence that openness causes financial depth for some countries.

Overall, while openness seems to be positively linked to financial development, the evidence for developing countries is less clear-cut. Furthermore, the coverage of African countries in previous contributions is typically limited. Finally, another strand of the literature focuses on the impact of financial development on openness. Svaleryd and Vlachos (2005) for example show that countries with relatively developed financial systems tend to promote export industries that are highly reliant on finance.

\section{THE DATA}

This section discusses the data used to build the panel covering 34 SSA economies for the period 1970-2009 used in the regression analysis. It also presents a brief rationale for the inclusion of control variables. The list of African countries studied is highlighted in Annex A. A description of variables used in our analysis is available in Annex B, and descriptive statistics for selected variables are provided in Annex C.

\section{Measuring Financial Development}

Choosing the right measure of financial development is not an obvious exercise and the literature has not settled on a common measure. Given the lack of general consensus, we take an agnostic view and build a comprehensive measure using factor analysis to extract a common factor from different indicators from the World Bank's Financial Structure database (Beck and Demirgüç-Kunt, 2009). These individual indicators have been used extensively in the literature, although they are frequently included separately as dependent variables rather than combined in a composite variable. 
Our comprehensive measure comprises the following set of indicators-liquid liabilities, credit to the private sector by deposit-taking banks, credit to the private sector by banks and other financial institutions, bank deposits, and financial system deposits, all as a share of GDP. For robustness, we also include a simple measure of credit to the private sector (as a share of GDP) — perhaps the most frequently used proxy for financial development — as a dependent variable in the regressions. Note that because of data availability problems for the countries considered in our sample, we excluded indicators of stock market development as well as those relating to the insurance industry.

The overall trend in financial sector development in SSA highlighted in the introduction masks considerable regional differences (Figure 2). Overall, the SADC region, which has higher average levels of per capita income than other regions, has had the highest level of financial development, although there was stagnation through most of the period. The EAC region has generally recorded more steady progress than other regions and has gradually caught up with the SADC. Until the mid-1990s, the WAEMU region had higher financial sector development than other regions (with the exception of the SADC). From this period until the mid-2000s, there has been stagnation. The CEMAC region follows a similar trend to that of the WAEMU, but in terms of absolute levels, the region had the lowest financial development indicators.

Figure 2.Financial Sector Development Indices for Selected Regions

SSA: Financial Sector Development Indices for Selected Regions

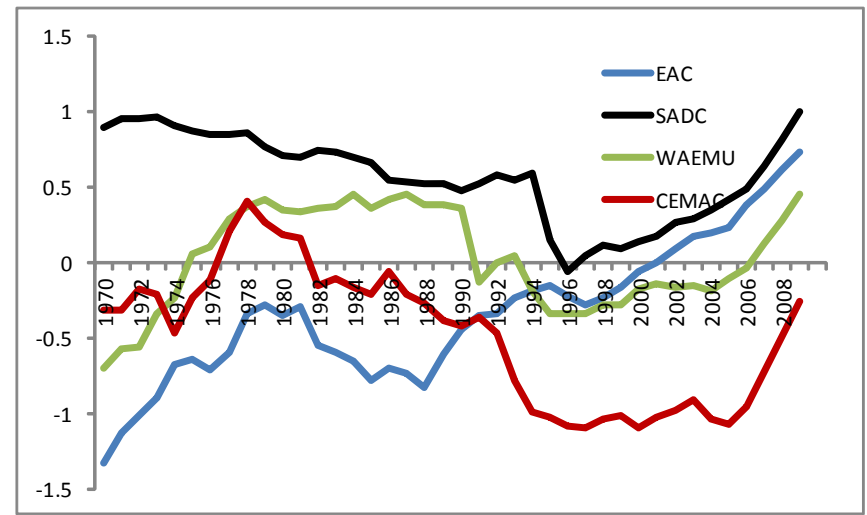

In order to get a better feel for the data, we look more closely at the private credit-to-GDP variable (Figure 3). The overall trend is broadly similar to the synthetic indices, but more pronounced. Thus there was rapid financial deepening in the 1970s until 1980 when the trend was sharply reversed through 1995. Indeed, by 1995, the level was actually lower than a generation earlier. Since 1996, there has been steady financial deepening. However, it is worth noting that the level of private credit to GDP at about 21 percent of GDP at the end of the period was roughly the same as in 1980. 
Figure 3.Private Credit to GDP

Private Credit to GDP

(percent)

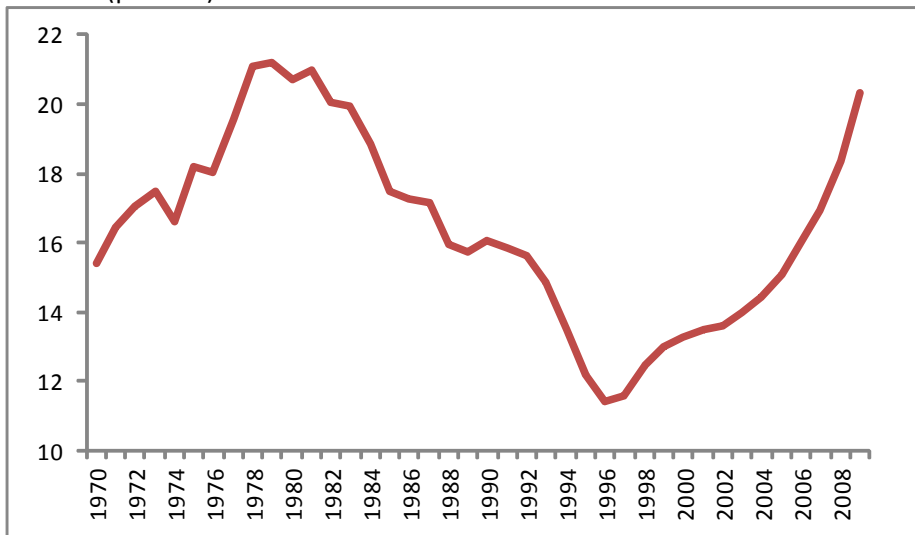

\section{Trade Openness, Financial Openness and Control Variables}

The main objective of this paper is to quantify the role of international financial and trade openness on financial development in sub-Saharan Africa. There are several alternative measures of trade openness suggested by the literature, amongst which the most widely used probably is the index constructed by Sachs and Warner (1995), which is a composite dummy variable built on five dummies that cover trade policies. In our analysis, we use a standard and intuitive measure of trade openness, the sum of exports and imports as a share of GDP. Contrary to the Sachs-Warner index, the measure used in this paper is a de facto (outcome) measure of trade openness and as such is determined by several factors in addition to trade policy itself (including structural characteristics such as geography). Ideally, we would like to use a policy-driven measure to assess openness to trade, but this was not possible because of data availability constraints both in terms of SSA country coverage and in terms of the time dimension. Despite the important shortcoming that our measure does not allow to identify the impact of trade policy on financial development, one should note that it allows assessing the still relevant question of the link between de facto openness and financial development, which is in line with the relationships suggested by the theoretical literature in any case.

Moreover, in order to measure restrictions to international financial integration, we use the index of capital account openness constructed by Chinn and Ito (2006) based on data from the IMF's Annual Report on Exchange Arrangements and Exchange Restrictions (AREAER). ${ }^{3}$ This measure has been widely used in the cross-country literature on capital

\footnotetext{
${ }^{3}$ Quinn, Schindler and Toyoda (2011) present a detailed discussion of the limitations of Chinn and Ito index and other measures of international financial integration. These authors point to a potential structural break in the Chinn-Ito index for the period 1995/96 based on changes in classification methodologies of the IMF's AREAER.
} 
account liberalization and the effects of financial openness on growth (see for example, Baltagi, Demetriades and Law, 2009). The fact that the index does not include measures of the effectiveness or the enforcement of these regulations constitutes one significant drawback of the data, which consequently does not capture de facto financial integration.

Nevertheless, alternative de facto measures of financial integration such as persistent interest rate differentials or the volume of a country's foreign assets and liabilities as a percentage of GDP (Lane and Milesi-Ferreti, 2006) do not allow us to isolate the impact of capital account regulations as these measures are driven by several additional factors (including exchange rate and country risk) and are more likely to suffer from endogeneity bias, as they are themselves determined by the level of financial development. Furthermore, data on alternative indicators of capital account openness (either de facto or de jure) typically is not available for a large number of sub-Saharan African countries.

In addition to trade and financial openness indicators, the regressions include a set of basic control variables commonly used in the literature on the determinants of financial development (Beck and Demirgüç-Kunt, 2009; Chinn and Ito, 2006; Tressel and Detragiache, 2008; Baltagi, Demetriades, and Law, 2009). These include notably the inflation rate, as high inflation is thought to discourage financial intermediation and might also be a proxy for macroeconomic instability (Boyd, Levine and Smith, 2001), and the log of per capita income in PPP terms. Per capita income is expected to be positively associated with financial development, as demand for financial instruments is higher in richer and more complex economies. Richer economies would also allow for greater economies of scale in the provision of financial services, hence also stimulating financial development from the supply-side (Allen and others, 2012).

Moreover, we consider a measure of institutional quality, constraints on the power of the executive $^{4}$ from the Polity IV database, which has been widely used in the empirical political economy literature as a proxy for the presence of "inclusive institutions" that foster the protection of property rights, reduce barriers to entry, and provide overall incentives for innovation and capital accumulation (Acemoglu and Johnson, 2005). Tressel and Detragiache (2008) also suggest that in countries with fewer constraints on the executive power, banks may be threatened by political interference in lending decisions, thus hampering the efficient allocation of credit.

Furthermore, financial development is expected to go hand in hand with financial reforms. Abiad, Detragiache, and Tressel (2010) present a database of various measures of financial

\footnotetext{
${ }^{4}$ This variable captures the official (de jure) discretionary leeway that the executive branch has in changing and implementing new policies.
} 
reforms and derive a financial reform index. ${ }^{5}$ Unfortunately, the coverage for SSA is limited to only 14 countries. The index shows that there were relatively few financial reforms in SSA until the early 1990s (Figure 4). In contrast, the 1990s were a period of rapid reforms, followed by a more moderate pace in the 2000s and SSA has generally caught up with the rest of the world.

Figure 4. Financial Reform Index

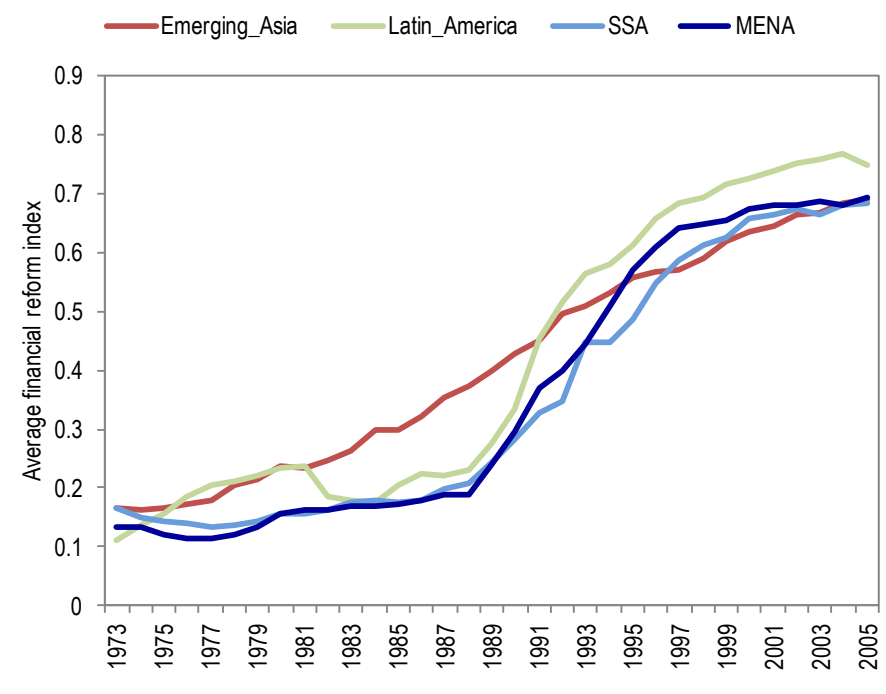

Source : Authors' calculations based on Abiad, Detragiache, and Tressel (2010)

In robustness checks we also include two additional control variables: changes in the terms of trade and the level of population density. Larger population density should affect financial development positively because of scale and networking effects, given that the provision of financial services is more efficient relative to sparsely populated countries (Allen and others, 2012). Movements in the terms of trade are expected to affect financial development through their impact on the profitability of tradables and thus the related attractiveness of financing them. In principle, countries benefiting from higher terms of trade growth should also see relatively higher financial development.

\section{A preliminary view of data associations}

A preliminary look at the data indicates that, for SSA countries, there is a positive relationship between trade openness and both measures of financial development (Figure 5, left panels). There is also overall evidence of a moderately positive association between financial development measures and capital account openness, although some countries with

\footnotetext{
${ }^{5}$ Covering credit controls and reserve requirements, interest rate controls, entry barriers, state ownership, policies on securities markets, banking regulations, and restrictions on the capital account.
} 
relatively well developed financial systems have relatively closed capital accounts (right panels in the Figure).

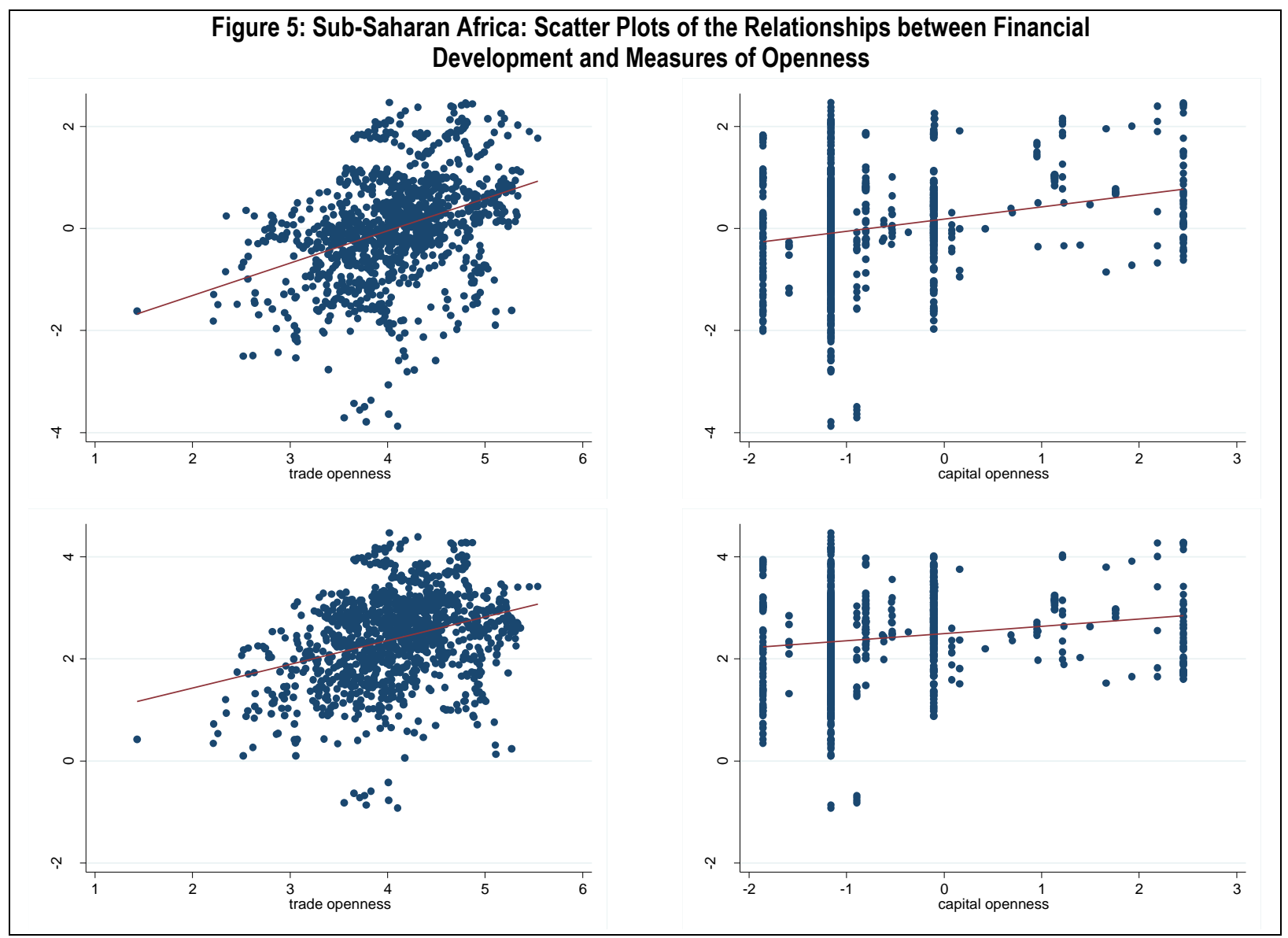

\section{Modeling Approach}

The general empirical specification followed in the analysis is summarized in Equation 1 for $i=1, \ldots, N$ countries; $t=1, \ldots, T$ time periods and $m=1, \ldots, M$ control variables.

$$
\begin{aligned}
& F D_{i t}=\rho_{i} F D_{i t-1}+\psi_{1 i} T O_{i t-1}+\psi_{2 i} F O_{i t-1}+\sum_{m=1}^{M} \beta_{m, i} X_{m, i, t-1}+u_{i t} \\
& u_{i t}=\alpha_{i}+\lambda_{i} f_{t}+\varepsilon_{i t}
\end{aligned}
$$

$F D$ represents the financial development measure; $T O$ and $F O$ are trade and financial openness measures respectively; $X$ is a set of control variables. $\alpha_{i}$ are country-specific fixedeffects intended to capture country characteristics that do not change over time; and $f_{t}$ is a common factor that affects all countries and changes over time and is not directly observable. 
This common factor is also allowed to affect the regressors in some specifications. $\varepsilon_{i t}$ is the error term, assumed to be white noise.

Although the economic interpretation of the common factor $\left(f_{t}\right)$ is not straightforward in a production function context, Eberhardt and Teal (2013) argue that it could be viewed as a measure of total factor productivity (TFP). In the context of this paper, the common factor could capture, for example, the impact of technological change (such as the introduction of ATMs or mobile phone technology) on financial development.

As one can note from Equation 1, the parameters $\psi_{1,} \psi_{2}$, and $\beta_{m}$ (i.e., the coefficients associated with trade openness, financial openness and the control variables); the parameter $\lambda$ (the factor loadings for the common dynamic factor); as well as the parameter $\rho$; are allowed to differ across countries. Standard dynamic panel estimators usually treat the dynamics and slope coefficients as homogeneous across panels and frequently require that stationarity of the variables be included in the analysis, which might not be appropriate assumptions for macroeconomic panels (Eberhardt and Teal, 2011).

In fact, Pesaran and Smith (1995) show that if the homogeneity assumption is violated, the coefficient estimates from pooled regressions become inconsistent. In addition, estimators traditionally used in panel data analysis require the assumption of cross-sectional independence across panel members. In the presence of cross-sectionally correlated error terms, these methods do not produce consistent estimates of the parameters of interest and can lead to incorrect inference (Kapetanios, Pesaran and Yamagata, 2011, Eberhardt and Teal, 2011). In order to address these shortcomings, we will use a set of estimators that allow for heterogeneity in slope coefficients, cross-sectional dependence, and perform well even when the series analyzed are non-stationary.

We present results from the estimation of the model above following three approaches. Firstly, we present results using the mean-group estimator (denoted MG in the regression tables) proposed by Pesaran and Smith (1995). The MG estimator allows for slope heterogeneity across countries, but does not address the issue of cross-section dependence. In Equation 1 above this essentially means that $\lambda_{i} f_{t}$ is ignored or simply modeled as a linear time trend. Nevertheless, in the presence of cross-sectional dependence, this estimator will be inconsistent and will lead to incorrect inference (Eberhardt and Teal, 2011).

In order to address potential problems of cross-sectional dependence, we also use the common correlated effects (CCEMG) estimator proposed by Pesaran (2006). This estimator uses cross-sectional averages of the dependent and independent variables as proxies for unobserved common factors in the regressions. The estimator yields consistent and efficient estimates and its small sample properties do not seem to be affected by residual serial 
correlation of the error terms (Kapetanios, Pesaran and Yamagata, 2011). Crucially, the CCEMG estimator performs well when variables included in the model are non-stationary.

Finally, we also consider results obtained when using the augmented mean-group estimator proposed by Bond and Eberhardt (2009), denoted AMG. Contrary to the CCEMG estimator, The AMG estimator includes the common factor $\left(f_{t}\right)$ as an explicit variable of interest in the regressions. It is implemented in three steps (Eberhardt, 2012). First, a pooled regression with year dummies is estimated by first difference OLS, and coefficients on year dummies are collected. These represent estimates of the evolution of the unobservable common dynamic process. Second, the country-specific regression model is augmented with the estimated common dynamic process as an explicit regressor. Finally, country-specific parameters are averaged across panel members. This estimator is shown to perform well (relatively small bias and more precise estimates) even in the context of variable and factor non-stationarity irrespective of whether the variables are co-integrated or not (Bond and Eberhardt, 2009).

\section{EMPIRICAL RESULTS}

Annex D presents panel unit root tests for the variables of interest. We focus on the tests proposed by Maddala and Wu (1999) and Pesaran (2007). Both tests allow for cross-sectional heterogeneity, but the Maddala and Wu test also assumes cross-sectional independence, whereas the Pesaran test models cross-sectional dependence in the form of one unobserved common factor. The tests clearly fail to reject the null of non-stationarity for all financial development measures considered and for the GDP per capita series, regardless of whether a trend is included in the model or not. The tests also strongly indicate that the trade openness series is stationary. Nevertheless, the results are more ambiguous for the capital account openness and inflation series.

\section{Baseline Regressions}

In light of the results of the unit root tests, we will present regressions ${ }^{6}$ for models including variables in levels (Table 1) and in first differences (Table 2) in order to mitigate problems related to non-stationarity, even if some of the estimators used perform well when variables are I(1). Looking at the determinants of changes in financial development is of interest in itself, in particular given the nature of our panel dataset, as an analysis of determinants of levels might be dominated by slow-moving structural country characteristics. In addition, the analysis of changes in financial development might also be relevant because the countries in our sample are developing economies that are likely to be transitioning between steady states over the period of analysis.

\footnotetext{
${ }^{6}$ Estimation was implemented in Stata 12 using the code written by Eberhardt (2012).
} 
First, we follow Baltagi, Demetriades and Law (2009) and estimate models including the levels of the variables of interest with explanatory variables lagged one period to mitigate endogeneity issues, i.e., we assume that regressors are weakly exogenous. Therefore, the results of the table correspond to an estimation of Equation 1 above. We do not detect a statistically significant effect of trade openness or capital account openness on financial sector development in all specifications. As far as capital account openness is concerned, the coefficient estimates obtained are small ranging from -0.02 to 0.004 , thus also pointing to an economically negligible impact as well. The magnitude of estimates for the impact of trade openness on financial development is also small in economic terms ranging from 0.02 to 0.08 .

The coefficients for other standard determinants of financial development are statistically significant in most specifications and have the expected signs, with the exception of the institutional quality variable. ${ }^{7}$ In particular, $\log (\mathrm{GDP})$ per capita is significant in all regressions with a short-run coefficient between 0.2 and 0.4 . As suggested by theory, inflation has negative and statistically significant impact on financial development (except for specification 6) with coefficients ranging from -0.21 to -0.34 . The common factor is highly significant in all specifications using the AMG estimator (specifications 3 and 4). This common factor could be capturing the influence of technological change (technology diffusion) on financial development in Africa.

The lack of significance of the institutional quality measure could perhaps be due to the overall low level of institutional development in the countries included in the sample (threshold effects) or because constraints on the executive power are a poor proxy for institutions that actually matter for financial development in Africa (such as creditor rights, insolvency regimes, land law, collateral registration rules, among others). A third possible explanation would be the high correlation between GDP per capita and institutional quality measures. Similar to our results, Allen and others (2012)_using cross-sectional regressions - also find that broad measures of institutional quality are less important in explaining banking sector development in Africa than in other developing regions. However, Tressel and Detragiache (2008) in a broader sample of countries find a statistically significant effect of the same institutional quality variable used here.

\footnotetext{
${ }^{7}$ The coefficient averages in the tables are computed as outlier robust means.
} 
Table 1. Estimation Results for Variables in Levels

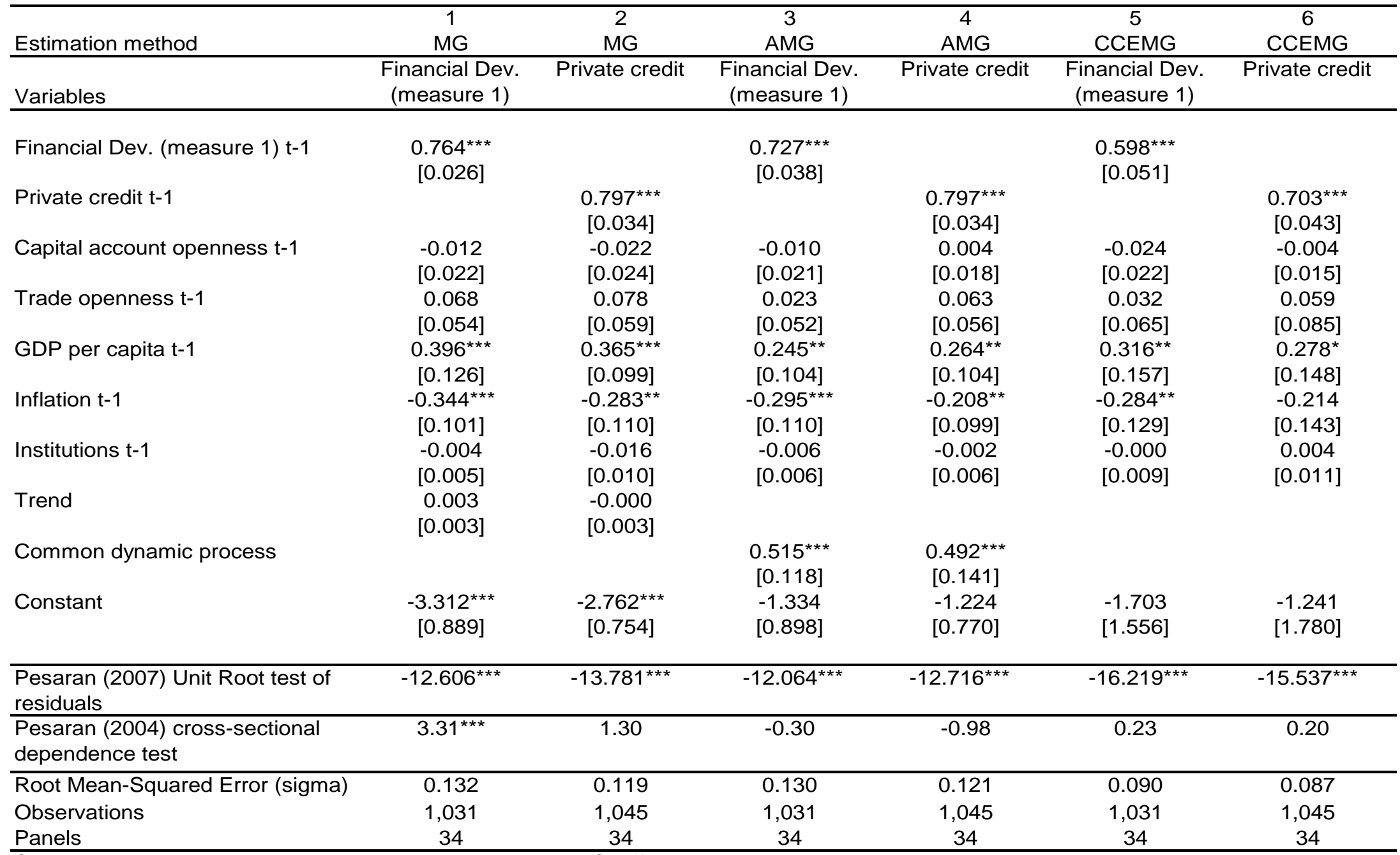

Standard errors in brackets. ${ }^{* * *} \mathrm{p}<0.01,{ }^{* *} \mathrm{p}<0.05,{ }^{*} \mathrm{p}<0.1$. Coefficient averages computed as outlier robust means.

MG refers to Pesaran and Smith (1995) mean-group estimator. AMG refers to Bond and Eberhardt (2009) augmented mean-group

estimator. CCEMG refers to Pesaran (2006) common correlated effects mean group estimator. For the latter approach, cross-sectional averaged regressors are not reported to save space. See the main text for discussion of different estimators. 
Regarding regression diagnostics, unit root tests on the residuals overwhelmingly reject the null of non-stationarity for all specifications, therefore suggesting that the estimated coefficients are not likely to be spurious. The cross-sectional dependence test proposed by Pesaran (2004) rejects the null of no cross-sectional dependence for one out of the two specifications using the MG estimator (see regressions 1 to 2), suggesting that inference from these regressions is likely to be invalid, but the test fails to reject the null for the AMG and CCEMG regressions (specifications 3 to 6). Therefore, the regressions using the AMG and CCEMG estimators are our preferred specifications.

We now turn to the estimation of the model with variables in first differences in order to address non-stationarity concerns and to investigate the correlates of changes in financial development measures, which might be of interest in itself. Therefore, we estimate regressions of the following from:

$$
\begin{aligned}
& \Delta F D_{i t}=\phi_{i} \Delta F D_{i, t-1}+\xi_{1 i} \Delta T O_{i, t-1}+\xi_{2 i} \Delta F O_{i, t-1}+\sum_{m=1}^{M} \varphi_{m, i} \Delta X_{m, i, t-1}+u_{i t} \\
& u_{i t}=\alpha_{i}+\lambda_{i} f_{t}+\varepsilon_{i t}
\end{aligned}
$$

Table 2 presents the results for these specifications. Overall, the results do not point to a statistically significant impact of trade and capital account openness on changes in financial development in Africa. Coefficient estimates for these variables are not only insignificant from a statistical point of view, but also small in terms of economic importance.

Furthermore, the results strongly suggest that changes in inflation affect changes in financial development negatively. The effect of the first difference of inflation on financial development is negative and statistically significant for all specifications with coefficients ranging from -0.14 to -0.33 . In addition, as expected, growth of GDP per capita has a positive impact on changes in financial development. The coefficients for GDP per capita growth are positive and statistically significant for most specifications, except for the ones using the CCEMG estimator (specifications 11 and 12). The Pesaran (2004) test strong rejects the null of cross-sectional independence for the residuals of all MG regressions (specifications 7 and 8 ), suggesting that these estimates should be interpreted with caution. 
Table 2. Estimation Results for Variables in First Differences

\begin{tabular}{|c|c|c|c|c|c|c|}
\hline Estimation method & $\begin{array}{c}7 \\
\mathrm{MG} \\
\end{array}$ & $\begin{array}{c}8 \\
M G \\
\end{array}$ & $\begin{array}{c}9 \\
\text { AMG }\end{array}$ & $\begin{array}{c}10 \\
\text { AMG }\end{array}$ & $\begin{array}{c}11 \\
\text { CCEMG }\end{array}$ & $\begin{array}{c}12 \\
\text { CCEMG }\end{array}$ \\
\hline Variables & $\begin{array}{c}\Delta \text { Financial Dev. } \\
\text { (measure } 1)\end{array}$ & $\Delta$ private credit & $\begin{array}{c}\Delta \text { Financial Dev. } \\
\text { (measure } 1)\end{array}$ & $\Delta$ private credit & $\begin{array}{c}\Delta \text { Financial Dev. } \\
\quad(\text { measure } 1)\end{array}$ & $\Delta$ private credit \\
\hline$\Delta$ Financial Dev. (measure 1) t-1 & $\begin{array}{c}0.348^{\star * *} \\
{[0.047]}\end{array}$ & & $\begin{array}{c}0.237^{* * *} \\
{[0.048]}\end{array}$ & & $\begin{array}{l}0.224^{\star * *} \\
{[0.071]}\end{array}$ & \\
\hline$\Delta$ Private credit $\mathrm{t}-1$ & & $\begin{array}{c}0.408^{* * *} \\
{[0.043]}\end{array}$ & & $\begin{array}{c}0.323^{\star * *} \\
{[0.043]}\end{array}$ & & $\begin{array}{l}0.390^{* * *} \\
{[0.058]}\end{array}$ \\
\hline$\Delta$ capital account openness $t-1$ & $\begin{array}{l}-0.011 \\
{[0.019]}\end{array}$ & $\begin{array}{l}-0.007 \\
{[0.018]}\end{array}$ & $\begin{array}{l}-0.001 \\
{[0.019]}\end{array}$ & $\begin{array}{c}0.000 \\
{[0.019]}\end{array}$ & $\begin{array}{l}-0.016 \\
{[0.030]}\end{array}$ & $\begin{array}{l}-0.007 \\
{[0.023]}\end{array}$ \\
\hline$\Delta$ trade openness $\mathrm{t}-1$ & $\begin{array}{c}0.060 \\
{[0.054]}\end{array}$ & $\begin{array}{c}0.047 \\
{[0.046]}\end{array}$ & $\begin{array}{c}0.046 \\
{[0.055]}\end{array}$ & $\begin{array}{c}0.032 \\
{[0.046]}\end{array}$ & $\begin{array}{c}0.024 \\
{[0.055]}\end{array}$ & $\begin{array}{l}-0.010 \\
{[0.063]}\end{array}$ \\
\hline GDP Growth t-1 & $\begin{array}{l}0.352^{* *} \\
{[0.137]}\end{array}$ & $\begin{array}{l}0.393^{\star * *} \\
{[0.121]}\end{array}$ & $\begin{array}{l}0.285^{\star *} \\
{[0.114]}\end{array}$ & $\begin{array}{l}0.332^{\star * *} \\
{[0.101]}\end{array}$ & $\begin{array}{c}0.008 \\
{[0.160]}\end{array}$ & $\begin{array}{c}0.135 \\
{[0.115]}\end{array}$ \\
\hline$\Delta$ Inflation $\mathrm{t}-1$ & $\begin{array}{c}-0.310^{* * *} \\
{[0.077]}\end{array}$ & $\begin{array}{c}-0.328^{\star * *} \\
{[0.069]}\end{array}$ & $\begin{array}{c}-0.334^{\star * *} \\
{[0.067]}\end{array}$ & $\begin{array}{c}-0.315^{\star \star *} \\
{[0.049]}\end{array}$ & $\begin{array}{l}-0.138^{*} \\
{[0.081]}\end{array}$ & $\begin{array}{c}-0.286^{* * *} \\
{[0.071]}\end{array}$ \\
\hline$\Delta$ Institutions $\mathrm{t}-1$ & $\begin{array}{l}-0.004 \\
{[0.007]}\end{array}$ & $\begin{array}{l}-0.008 \\
{[0.005]}\end{array}$ & $\begin{array}{l}-0.001 \\
{[0.008]}\end{array}$ & $\begin{array}{l}-0.006 \\
{[0.006]}\end{array}$ & $\begin{array}{l}-0.003 \\
{[0.006]}\end{array}$ & $\begin{array}{l}-0.001 \\
{[0.004]}\end{array}$ \\
\hline Common dynamic process & & & $\begin{array}{l}0.625^{\star \star *} \\
{[0.108]}\end{array}$ & $\begin{array}{l}0.593^{\star \star *} \\
{[0.124]}\end{array}$ & & \\
\hline Constant & $\begin{array}{l}0.018^{* * *} \\
{[0.005]}\end{array}$ & $\begin{array}{c}0.007 \\
{[0.004]}\end{array}$ & $\begin{array}{l}0.137^{* * *} \\
{[0.020]}\end{array}$ & $\begin{array}{l}0.034^{* * *} \\
{[0.008]}\end{array}$ & $\begin{array}{l}-0.002 \\
{[0.010]}\end{array}$ & $\begin{array}{l}-0.004 \\
{[0.007]}\end{array}$ \\
\hline $\begin{array}{l}\text { Pesaran (2004) cross-sectional } \\
\text { dependence test }\end{array}$ & $6.21^{* \star *}$ & $3.71^{\star \star *}$ & -0.68 & -0.76 & -0.10 & 0.15 \\
\hline Root Mean-Squared Error (sigma) & 0.151 & 0.130 & 0.140 & 0.121 & 0.102 & 0.096 \\
\hline $\begin{array}{l}\text { Observations } \\
\text { Panels }\end{array}$ & $\begin{array}{c}997 \\
34\end{array}$ & $\begin{array}{c}1,011 \\
34\end{array}$ & $\begin{array}{c}997 \\
34\end{array}$ & $\begin{array}{c}1,011 \\
34\end{array}$ & $\begin{array}{c}997 \\
34\end{array}$ & $\begin{array}{c}1,011 \\
34\end{array}$ \\
\hline
\end{tabular}

Standard errors in brackets. ${ }^{* *} p<0.01,{ }^{* *} p<0.05,{ }^{*} p<0.1$. Coefficient averages computed as outlier robust means.

MG refers to Pesaran and Smith (1995) mean-group estimator. AMG refers to Bond and Eberhardt (2009) augmented mean-group

estimator. CCEMG refers to Pesaran (2006) common correlated effects mean group estimator. For the latter approach, cross-sectional averaged regressors are not reported to save space. See the main text for discussion of different estimators. 


\section{Alternative Sample Periods}

Given that in Section III we have identified that our measures of financial development have evolved differently over three distinct time periods over the past 40 years, we propose to also estimate models (in levels and first differences) for these specific periods. The results for the period 1996-2009 are qualitatively similar to the ones discussed previously and are not reported to save space. ${ }^{8}$ But when looking at the period 1982 to 1995 (Table 3), the coefficient for the trade openness measure becomes significant in a number of specifications with the expected positive sign (see specifications 14-15 and 18-21).

Unfortunately, because of the restricted time dimension we also lose observations for quite a few countries, which results in a much reduced overall sample (less than 350 observations). The results on capital account openness are more mixed, but broadly do not point to any effect. Results for the other controls are similar to what we obtain using the whole sample. Diagnostic tests cannot reject a unit root for the residuals of two specifications (15 and 18) and point to cross-sectional dependence in 2 specifications (17 and 18). Overall, these results should be interpreted with caution and appear less robust than the ones discussed previously. In addition to problems related to sample size, it is also probable that selection bias might become an issue here, given that countries for which data is available over the earlier time periods are likely to be countries that perform better.

\section{Further Discussion of Results in the Context of the Empirical Literature}

The finding that trade and capital account openness are not significant determinants of financial development in Sub-Saharan Africa when controlling for other factors is broadly in line with the results obtained by Tressel and Detragiache (2008) for a broader sample of developing and advanced economies. These authors find that trade and capital account liberalization do not have a significant effect on financial development when controlling for domestic banking sector liberalization. Our results also confirm some of the analysis of Gries, Kraft and Meierrieks (2009). Using single country time series techniques for 16 African countries, these authors find that there is a link between financial development and trade openness in some of the countries in their sample, but this link is not robust.

But the conclusions of our analysis are in stark contrast with the findings in Baltagi, Demetriades and Law (2009) for a larger set of developing countries and advanced economies, which point to a robust impact of trade and capital account openness on financial development. These differences may partly be a reflection of different composition of the countries used in the sample as well as econometric techniques, but may also point to deeper economic and structural reasons.

\footnotetext{
${ }^{8}$ The results are available from the authors' upon request.
} 
Table 3. Estimation Results over Period 1982-1995

\begin{tabular}{|c|c|c|c|c|c|c|c|c|c|}
\hline Estimation Method & \begin{tabular}{|c|}
$\mathrm{MG}$ \\
13
\end{tabular} & $\begin{array}{c}\text { AMG } \\
14\end{array}$ & $\begin{array}{c}\text { CCE } \\
15\end{array}$ & \begin{tabular}{|c|} 
MG \\
16
\end{tabular} & $\begin{array}{c}\text { AMG } \\
17\end{array}$ & \begin{tabular}{|c|}
$\mathrm{CCE}$ \\
18
\end{tabular} & $\begin{array}{c}\text { MG } \\
19\end{array}$ & $\frac{\text { AMG }}{20}$ & $\frac{\text { CCE }}{21}$ \\
\hline VARIABLES & Financial Dev. & Financial Dev. & Financial Dev. & Private Credit & Private Credit & Private Credit & $\Delta$ Financial Dev. & $\Delta$ Financial Dev. & $\Delta$ Financial Dev. \\
\hline Financial Dev. t-1 & $\begin{array}{c}0.394^{* * *} \\
{[0.108]}\end{array}$ & $\begin{array}{c}0.484^{\star * *} \\
{[0.083]}\end{array}$ & $\begin{array}{c}0.229 \\
{[0.252]}\end{array}$ & & & & $\begin{array}{c}-0.477^{\star * *} \\
{[0.085]}\end{array}$ & $\begin{array}{c}-0.516^{* * *} \\
{[0.083]}\end{array}$ & $\begin{array}{c}-0.740^{\star * *} \\
{[0.231]}\end{array}$ \\
\hline Private credit $\mathrm{t}-1$ & & & & $\begin{array}{c}0.500^{* * *} \\
{[0.099]}\end{array}$ & $\begin{array}{c}0.584^{\star * *} \\
{[0.068]}\end{array}$ & $\begin{array}{c}0.782^{* * *} \\
{[0.142]}\end{array}$ & & & \\
\hline Capital account openness t-1 & $\begin{array}{l}-0.060^{*} \\
{[0.032]}\end{array}$ & $\begin{array}{l}-0.032 \\
{[0.032]}\end{array}$ & $\begin{array}{l}-0.055^{*} \\
{[0.029]}\end{array}$ & $\begin{array}{l}-0.032 \\
{[0.023]}\end{array}$ & $\begin{array}{c}-0.061^{* *} \\
{[0.029]}\end{array}$ & $\begin{array}{c}0.013 \\
{[0.036]}\end{array}$ & $\begin{array}{l}-0.047 \\
{[0.037]}\end{array}$ & $\begin{array}{l}-0.032 \\
{[0.032]}\end{array}$ & $\begin{array}{l}-0.018 \\
{[0.033]}\end{array}$ \\
\hline Trade openness t- 1 & $\begin{array}{c}0.153 \\
{[0.120]}\end{array}$ & $\begin{array}{l}0.154^{* *} \\
{[0.073]}\end{array}$ & $\begin{array}{c}0.442^{*} \\
{[0.233]}\end{array}$ & $\begin{array}{c}0.125 \\
{[0.119]}\end{array}$ & $\begin{array}{c}0.076 \\
{[0.098]}\end{array}$ & $\begin{array}{c}0.416^{\star * *} \\
{[0.160]}\end{array}$ & $\begin{array}{l}0.185^{\star *} \\
{[0.085]}\end{array}$ & $\begin{array}{l}0.154^{* *} \\
{[0.073]}\end{array}$ & $\begin{array}{l}0.484^{*} \\
{[0.247]}\end{array}$ \\
\hline GDP per capita t-1 & $\begin{array}{l}0.304^{*} \\
{[0.156]}\end{array}$ & $\begin{array}{l}0.412^{* *} \\
{[0.187]}\end{array}$ & $\begin{array}{l}0.582^{*} \\
{[0.340]}\end{array}$ & $\begin{array}{l}0.395^{* *} \\
{[0.199]}\end{array}$ & $\begin{array}{c}0.364 \\
{[0.260]}\end{array}$ & $\begin{array}{l}1.035^{* *} \\
{[0.434]}\end{array}$ & $\begin{array}{l}0.481^{* *} \\
{[0.197]}\end{array}$ & $\begin{array}{l}0.412^{* *} \\
{[0.187]}\end{array}$ & $\begin{array}{l}0.630^{*} \\
{[0.359]}\end{array}$ \\
\hline Inflation t-1 & $\begin{array}{c}-0.397^{\star * *} \\
{[0.119]}\end{array}$ & $\begin{array}{c}-0.496^{* * *} \\
{[0.122]}\end{array}$ & $\begin{array}{l}-0.231 \\
{[0.321]}\end{array}$ & $\begin{array}{c}-0.468^{* * *} \\
{[0.121]}\end{array}$ & $\begin{array}{c}-0.438^{* * *} \\
{[0.127]}\end{array}$ & $\begin{array}{c}0.148 \\
{[0.353]}\end{array}$ & $\begin{array}{c}-0.440^{* * *} \\
{[0.112]}\end{array}$ & $\begin{array}{c}-0.496^{* * *} \\
{[0.122]}\end{array}$ & $\begin{array}{l}-0.207 \\
{[0.324]}\end{array}$ \\
\hline Institutions t-1 & $\begin{array}{c}0.002 \\
{[0.011]}\end{array}$ & $\begin{array}{l}-0.010 \\
{[0.011]}\end{array}$ & $\begin{array}{c}0.008 \\
{[0.027]}\end{array}$ & $\begin{array}{l}-0.005 \\
{[0.013]}\end{array}$ & $\begin{array}{c}-0.013^{* *} \\
{[0.005]}\end{array}$ & $\begin{array}{l}-0.003 \\
{[0.020]}\end{array}$ & $\begin{array}{l}-0.014 \\
{[0.016]}\end{array}$ & $\begin{array}{l}-0.010 \\
{[0.011]}\end{array}$ & $\begin{array}{c}0.018 \\
{[0.031]}\end{array}$ \\
\hline Trend & $\begin{array}{l}-0.001 \\
{[0.009]}\end{array}$ & & & $\begin{array}{l}-0.008 \\
{[0.007]}\end{array}$ & & & & & \\
\hline Common Dynamic Process & & $\begin{array}{c}0.664 \\
{[0.442]}\end{array}$ & & & $\begin{array}{l}0.720^{* *} \\
{[0.328]}\end{array}$ & & & $\begin{array}{c}0.664 \\
{[0.442]}\end{array}$ & \\
\hline Constant & $\begin{array}{c}-3.186^{* * *} \\
{[0.946]}\end{array}$ & $\begin{array}{c}-3.815^{\star \star \star} \\
{[1.175]}\end{array}$ & $\begin{array}{c}4.440 \\
{[7.054]}\end{array}$ & $\begin{array}{l}-1.995^{\star} \\
{[1.117]}\end{array}$ & $\begin{array}{l}-2.007 \\
{[2.034]}\end{array}$ & $\begin{array}{l}-9.167 \\
{[8.000]}\end{array}$ & $\begin{array}{c}-4.826^{\star \star \star} \\
{[1.329]}\end{array}$ & $\begin{array}{c}-3.815^{\star * *} \\
{[1.175]}\end{array}$ & $\begin{array}{c}2.419 \\
{[6.199]}\end{array}$ \\
\hline $\begin{array}{l}\text { Pesaran (2007) Unit Root test of } \\
\text { residuals }\end{array}$ & $-4.54^{\star \star \star}$ & $-7.78^{\star \star \star}$ & 9.15 & $-3.92^{\star \star \star}$ & $-4.23^{\star \star *}$ & 10.82 & $-5.16^{\star \star \star}$ & $-7.78^{\star \star \star}$ & 9.152 \\
\hline $\begin{array}{l}\text { Pesaran (2004) cross-sectional } \\
\text { dependence test }\end{array}$ & -0.68 & -1.13 & 0.85 & 0.46 & $-1.80^{*}$ & $1.98^{\star *}$ & 0.01 & -1.13 & -0.06 \\
\hline Root Mean-Squared Error (sigma) & 0.109 & 0.074 & 0.015 & 0.080 & 0.073 & 0.012 & 0.130 & 0.074 & 0.015 \\
\hline Observations & 349 & 349 & 349 & 349 & 349 & 349 & 349 & 349 & 349 \\
\hline Panels & 26 & 26 & 26 & 26 & 26 & 26 & 26 & 26 & 26 \\
\hline
\end{tabular}

Standard errors in brackets. ${ }^{* * *} \mathrm{p}<0.01,{ }^{* *} \mathrm{p}<0.05{ }^{*} \mathrm{p}<0.1$. Coefficient averages computed as outlier robust means.

MG refers to Pesaran and Smith (1995) mean-group estimator. AMG refers to Bond and Eberhardt (2009) augmented mean-group estimator. CCEMG refers to Pesaran (2006) common

correlated effects mean group estimator. For the latter approach, cross-sectional averaged regressors are not reported to save space. See the main text for discussion of different estimators. 
One possible hypothesis is that in the presence of large distortions in domestic financial markets (such as interest rate controls, directed credit, barriers to entry, among others), greater openness would not translate into direct gains in terms of financial development. One implication is that the effects of domestic financial sector reforms would dominate the effects of greater openness in terms of promoting financial development. This hypothesis would be in line with the conclusions of Tressel and Detragiache (2008).

Another possible explanation relates to the empirical findings by Chinn and Ito (2006), which conclude that greater openness would only translate into greater financial development after a threshold of legal/institutional development is passed. If institutions are generally weaker in sub-Saharan African countries, one would not be able to detect gains from greater openness. Henry (2007) also provides a clear example of such effects when discussing the impact of capital account liberalization on growth. Weak institutions would invalidate the standard prediction by the neoclassical growth model that capital would flow from rich to poor countries in the absence of capital controls. This occurs because the rate of return on capital might not be higher in developing economies if the institutional framework does not support an efficient allocation of resources and secure appropriation of profits.

A third hypothesis, perhaps related to the quality of institutions explanation, stresses the role of appropriate supervision in the financial sector. In an environment where supervision is weak, greater openness might actually increase vulnerabilities to shocks or bubbles with obvious negative implications in terms of financial deepening, including reversals.

\section{The Role of Financial Sector Reforms}

In order to attempt to address some of these issues, we estimated the models over the entire sample period and included as an addition control variable the index of financial reforms constructed by Abiad, Detragiache and Tressel (2010). The results are presented on Table 4. Unfortunately, the index is only available for 13 SSA countries, which significantly reduces the overall sample size for the estimation (370 observations).

In this case, trade openness seems to matter in a number of specifications $(23-24,26,28-30)$ with positive coefficients ranging from 0.15 to 0.21 , but financial reforms themselves do not present much of an impact, which in itself constitutes a puzzle and deviates from findings for a broader sample of countries. As before, capital account openness continues to present insignificant direct effects on financial development (both statistically and economically). Diagnostic tests indicate problems with cross-sectional dependence for 4 specifications (24, 26, 27, and 30), so results are less reliable than the ones presented in Tables 1 and 2.

We also experimented with estimation over different time periods, but the basic conclusions are not changed. Once again, selection bias might be a concern for these specifications given the much reduced number of countries included. 
Table 4. Estimation Results Including Financial Reforms

\begin{tabular}{|c|c|c|c|c|c|c|c|c|c|}
\hline Estimation Method & $\begin{array}{c}M G \\
22\end{array}$ & $\begin{array}{c}\text { AMG } \\
23\end{array}$ & $\begin{array}{c}\text { CCE } \\
24\end{array}$ & $\begin{array}{c}M G \\
25\end{array}$ & $\begin{array}{c}\text { AMG } \\
26\end{array}$ & $\begin{array}{c}\text { CCE } \\
27\end{array}$ & $\begin{array}{c}M G \\
28\end{array}$ & $\begin{array}{c}\text { AMG } \\
29\end{array}$ & $\begin{array}{c}\text { CCE } \\
30\end{array}$ \\
\hline VARIABLES & Financial Dev. & Financial Dev. & Financial Dev. & Private Credit & Private Credit & Private Credit & $\Delta$ Financial Dev. & $\Delta$ Financial Dev. & $\Delta$ Financial Dev. \\
\hline Financial Dev. t-1 & $\begin{array}{c}0.724^{\star * *} \\
{[0.024]}\end{array}$ & $\begin{array}{c}0.599^{\star \star *} \\
{[0.061]}\end{array}$ & $\begin{array}{c}0.507^{\star \star *} \\
{[0.085]}\end{array}$ & & & & $\begin{array}{c}-0.314^{* * *} \\
{[0.026]}\end{array}$ & $\begin{array}{c}-0.401^{\star * *} \\
{[0.061]}\end{array}$ & $\begin{array}{c}-0.493^{\star * *} \\
{[0.085]}\end{array}$ \\
\hline Private credit t-1 & & & & $\begin{array}{c}0.732^{\star \star *} \\
{[0.054]}\end{array}$ & $\begin{array}{c}0.664^{* * *} \\
{[0.067]}\end{array}$ & $\begin{array}{c}0.545^{\star \star \star} \\
{[0.070]}\end{array}$ & & & \\
\hline Capital account openness t- 1 & $\begin{array}{c}-0.006 \\
{[0.033]}\end{array}$ & $\begin{array}{c}-0.014 \\
{[0.030]}\end{array}$ & $\begin{array}{l}-0.010 \\
{[0.039]}\end{array}$ & $\begin{array}{c}-0.028 \\
{[0.030]}\end{array}$ & $\begin{array}{l}-0.039 \\
{[0.049]}\end{array}$ & $\begin{array}{c}-0.047 \\
{[0.044]}\end{array}$ & $\begin{array}{c}-0.005 \\
{[0.032]}\end{array}$ & $\begin{array}{c}-0.014 \\
{[0.030]}\end{array}$ & $\begin{array}{c}-0.010 \\
{[0.039]}\end{array}$ \\
\hline Trade openness $t-1$ & $\begin{array}{c}0.080 \\
{[0.078]}\end{array}$ & $\begin{array}{l}0.147^{\star \star} \\
{[0.064]}\end{array}$ & $\begin{array}{l}0.205^{\star} \\
{[0.107]}\end{array}$ & $\begin{array}{c}0.015 \\
{[0.078]}\end{array}$ & $\begin{array}{c}0.186^{* \star \star} \\
{[0.045]}\end{array}$ & $\begin{array}{c}0.155 \\
{[0.121]}\end{array}$ & $\begin{array}{l}0.125^{\star} \\
{[0.073]}\end{array}$ & $\begin{array}{l}0.147^{\star *} \\
{[0.064]}\end{array}$ & $\begin{array}{l}0.205^{\star} \\
{[0.107]}\end{array}$ \\
\hline GDP per capita t-1 & $\begin{array}{c}0.451^{* * *} \\
{[0.174]}\end{array}$ & $\begin{array}{l}0.378^{* *} \\
{[0.147]}\end{array}$ & $\begin{array}{l}0.327^{* *} \\
{[0.154]}\end{array}$ & $\begin{array}{c}0.339^{*} \\
{[0.198]}\end{array}$ & $\begin{array}{c}0.163 \\
{[0.202]}\end{array}$ & $\begin{array}{c}0.162 \\
{[0.158]}\end{array}$ & $\begin{array}{l}0.451^{\text {** }} \\
{[0.187]}\end{array}$ & $\begin{array}{l}0.378^{* *} \\
{[0.147]}\end{array}$ & $\begin{array}{l}0.327^{* *} \\
{[0.154]}\end{array}$ \\
\hline Inflation t-1 & $\begin{array}{c}-0.381^{* * *} \\
{[0.126]}\end{array}$ & $\begin{array}{c}-0.367^{* * *} \\
{[0.131]}\end{array}$ & $\begin{array}{c}-0.345^{\star \star \star} \\
{[0.129]}\end{array}$ & $\begin{array}{c}-0.313^{\star *} \\
{[0.125]}\end{array}$ & $\begin{array}{c}-0.346^{\star * *} \\
{[0.081]}\end{array}$ & $\begin{array}{l}-0.292^{\star *} \\
{[0.124]}\end{array}$ & $\begin{array}{c}-0.493^{\star * *} \\
{[0.129]}\end{array}$ & $\begin{array}{c}-0.367^{\star * *} \\
{[0.131]}\end{array}$ & $\begin{array}{c}-0.345^{\star \star \star} \\
{[0.129]}\end{array}$ \\
\hline Institutions t-1 & $\begin{array}{c}-0.001 \\
{[0.009]}\end{array}$ & $\begin{array}{l}-0.006 \\
{[0.010]}\end{array}$ & $\begin{array}{l}-0.006 \\
{[0.016]}\end{array}$ & $\begin{array}{l}-0.002 \\
{[0.005]}\end{array}$ & $\begin{array}{l}-0.002 \\
{[0.005]}\end{array}$ & $\begin{array}{c}0.002 \\
{[0.012]}\end{array}$ & $\begin{array}{l}-0.004 \\
{[0.007]}\end{array}$ & $\begin{array}{l}-0.006 \\
{[0.010]}\end{array}$ & $\begin{array}{l}-0.006 \\
{[0.016]}\end{array}$ \\
\hline Financial Reform t-1 & $\begin{array}{c}-0.008 \\
{[0.229]}\end{array}$ & $\begin{array}{c}-0.211^{* *} \\
{[0.107]}\end{array}$ & $\begin{array}{c}-0.325 \\
{[0.256]}\end{array}$ & $\begin{array}{l}-0.103 \\
{[0.248]}\end{array}$ & $\begin{array}{c}0.005 \\
{[0.164]}\end{array}$ & $\begin{array}{l}-0.128 \\
{[0.307]}\end{array}$ & $\begin{array}{c}-0.130 \\
{[0.162]}\end{array}$ & $\begin{array}{c}-0.211^{* *} \\
{[0.107]}\end{array}$ & $\begin{array}{c}-0.325 \\
{[0.256]}\end{array}$ \\
\hline Trend & $\begin{array}{c}-0.002 \\
{[0.003]}\end{array}$ & & & $\begin{array}{c}0.004 \\
{[0.005]}\end{array}$ & & & & & \\
\hline Common Dynamic Process & & $\begin{array}{l}0.632^{* *} \\
{[0.301]}\end{array}$ & & & $\begin{array}{c}0.828^{* * *} \\
{[0.286]}\end{array}$ & & & $\begin{array}{l}0.632^{* *} \\
{[0.301]}\end{array}$ & \\
\hline Constant & $\begin{array}{c}-3.152^{* * *} \\
{[1.001]}\end{array}$ & $\begin{array}{c}-2.447^{\star *} \\
{[1.027]}\end{array}$ & $\begin{array}{c}-0.996 \\
{[1.427]}\end{array}$ & $\begin{array}{c}-1.686 \\
{[1.060]}\end{array}$ & $\begin{array}{l}-0.488 \\
{[1.130]}\end{array}$ & $\begin{array}{l}-0.878 \\
{[2.507]}\end{array}$ & $\begin{array}{c}-3.425^{\star * *} \\
{[1.123]}\end{array}$ & $\begin{array}{c}-2.447^{\star *} \\
{[1.027]}\end{array}$ & $\begin{array}{c}-0.996 \\
{[1.427]}\end{array}$ \\
\hline $\begin{array}{l}\text { Pesaran (2007) Unit Root test of } \\
\text { residuals }\end{array}$ & $-8.36^{* * *}$ & $-9.54^{* * *}$ & $-10.51^{* * *}$ & $-8.01^{\star \star \star}$ & $-8.41^{* * *}$ & $-10.56^{* * *}$ & $-8.45^{\star * *}$ & $-9.24^{\star \star *}$ & $-10.51^{* * *}$ \\
\hline $\begin{array}{l}\text { Pesaran (2004) cross-sectional } \\
\text { dependence test }\end{array}$ & 1.44 & -0.78 & $-1.98^{* *}$ & 1.30 & $-1.96^{* *}$ & $-1.68^{*}$ & 1.21 & -0.78 & $-1.81^{*}$ \\
\hline Root Mean-Squared Error (sigma) & & & & & & & & & \\
\hline Observations & 370 & 370 & 370 & 370 & 370 & 370 & 370 & 370 & 370 \\
\hline Panels & 13 & 13 & 13 & 13 & 13 & 13 & 13 & 13 & 13 \\
\hline
\end{tabular}




\section{Variation across-countries in coefficients for capital account and trade openness}

Heterogeneity among the countries considered in our sample was one of the key motivations behind the choice of statistical techniques employed in the paper. Although in general we do not find a strong link between financial development and openness in Africa, this conclusion does not necessarily hold for all countries. In this context, it is of interest investigate the dispersion across countries of the coefficients obtained for openness measures and possible systematic patterns in the variation of these coefficients.

In Figure 6 we examine the cross-sectional association between the coefficients for capital account and trade openness obtained in the regressions and certain country characteristics, namely institutional quality and the overall level of economic development. In the top two panels of the Figure, we present scatter plots that relate the country-specific coefficients obtained when estimating specification 3 in Table 1 (AMG estimator) with the average value over the sample period for a given country for the constraint on the executive variable. The plots suggest no association between coefficients for both measures of openness and this measure of institutional quality, thus mirroring general results.

Furthermore, in the middle panels of the Figure, we also examine the association between the country-specific coefficients and an alternative measure of institutional quality, namely the indicator of the quality of bureaucracy from International Country Risk Guide (ICRG). In this case, we find stronger evidence of a possible positive link between institutional quality and the coefficients obtained for trade openness, i.e., countries with higher institutional quality also tend to present more positive coefficients for trade openness in the regression. Nevertheless, we could not find a strong association between the coefficients for capital account openness and this measure of institutional quality. We also consider the link between the coefficients obtained for trade and capital account openness, and the level of GDP per capita in 2005 (bottom panels of the Figure), and we do not find an association.

In Figure 7, we repeat the previous exercise for the specification in first differences (Table 2) focusing on the associations between institutional quality measures and the coefficients obtained. ${ }^{9}$ Once again, we could not detect a significant association between the coefficients for capital account openness and measures of institutional quality. Nonetheless, the link between trade openness coefficients and both measures of institutional quality is much stronger in this instance.

\footnotetext{
${ }^{9}$ Scatter plots of the coefficients for openness and the level of development do not show a significant link (as in Figure 6) and are not reported to save space.
} 
Overall, we can conclude that there is some indication that trade openness is more important for financial development in countries with better institutional quality. Nevertheless, it does not seem that institutional quality matters for the importance of capital account openness for financial development in African economies.

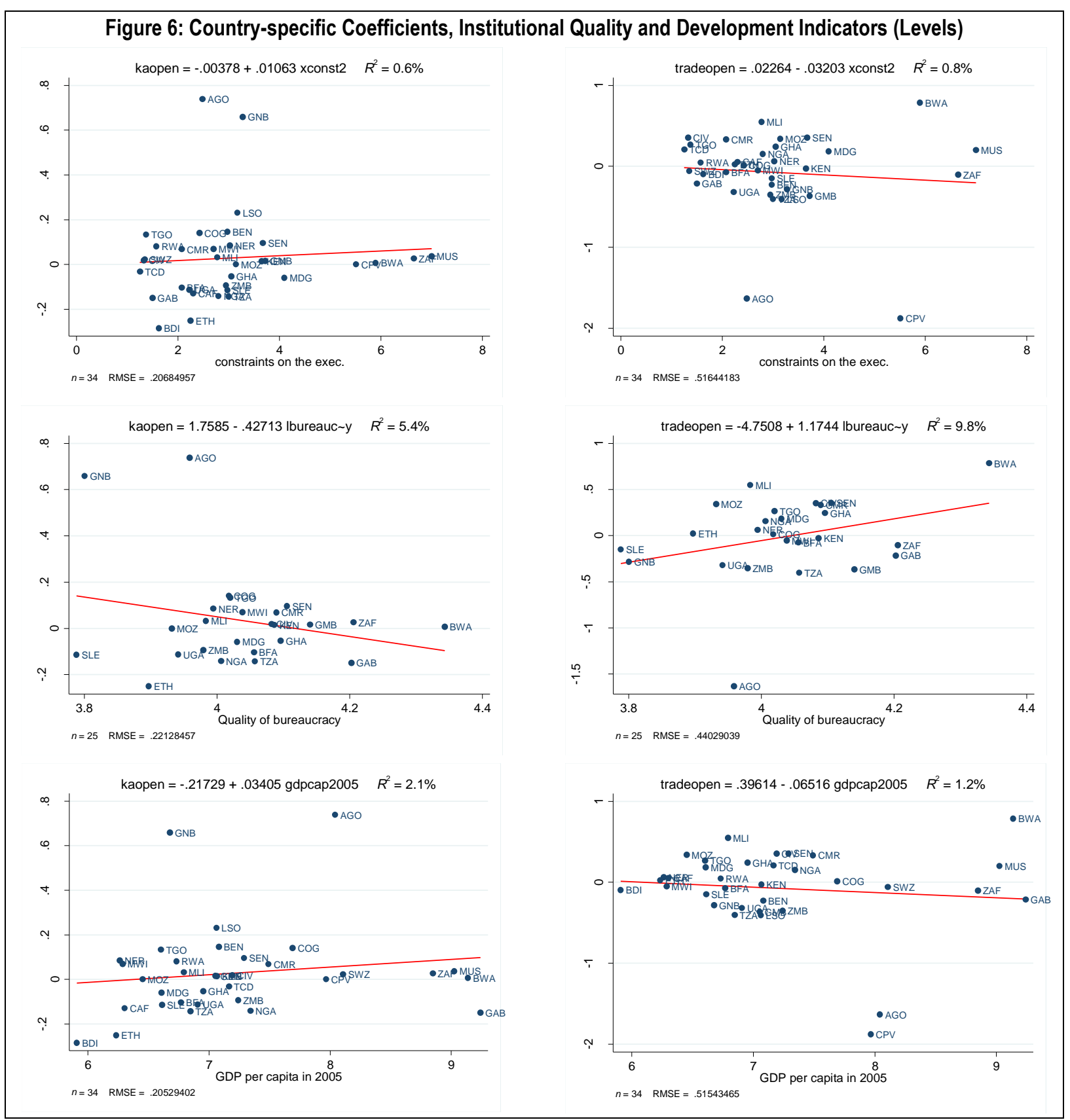

Note: Scatter plots depict country-specific estimates vs. institutional quality and development variables. Country-specific coefficient estimates based on specification 3 in Table 1 (using AMG estimator). Constraints on the executive and quality of bureaucracy indicators are country-specific averages across the sample period. Log of real GDP per capita in 2005 was used for bottom two panels. 


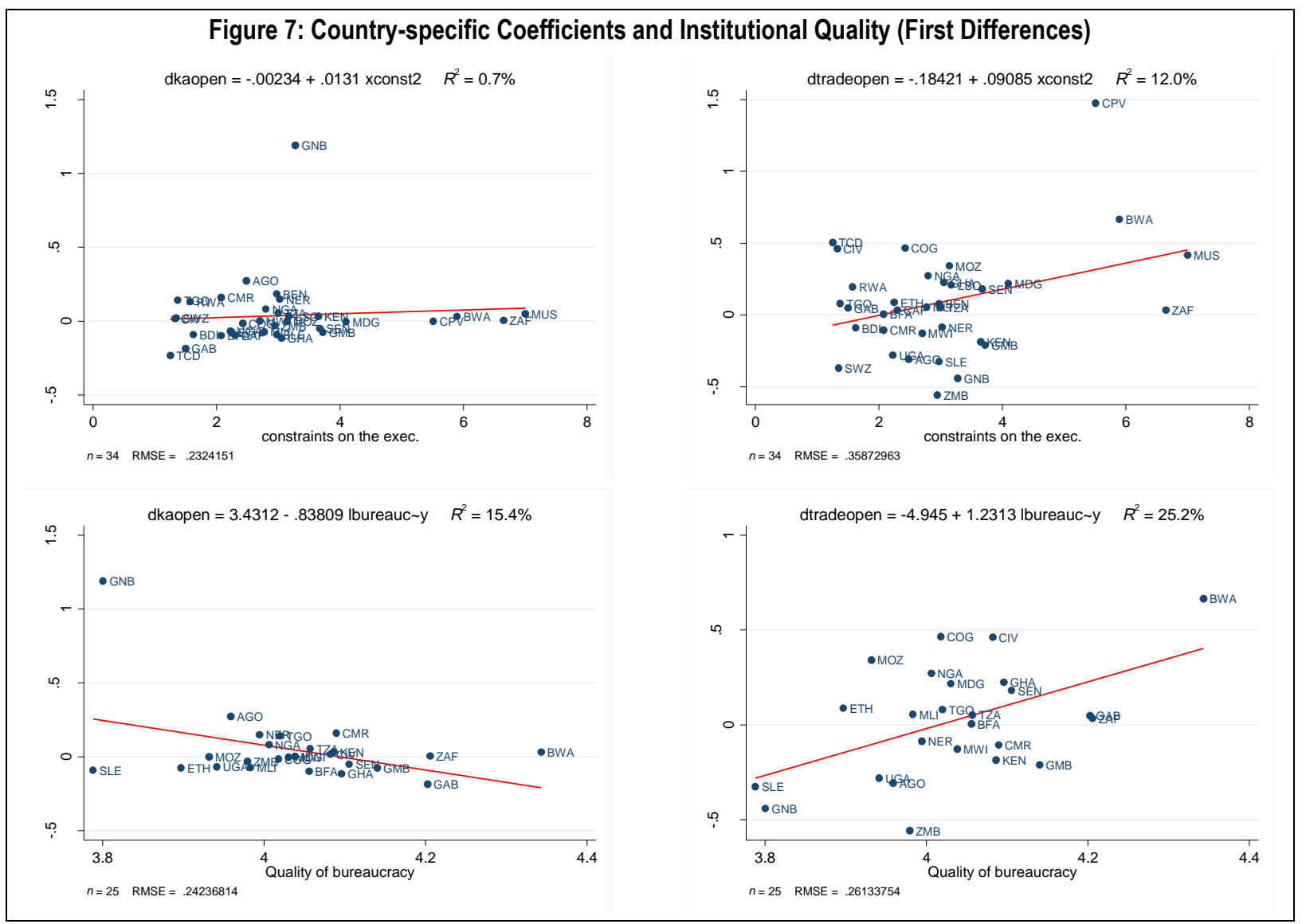

Note: Scatter plots depict country-specific coefficients vs. institutional quality. Country-specific coefficient estimates based on specification 9 in Table 2 (using AMG estimator). Constraints on the executive and quality of bureaucracy indicators are country-specific averages across the sample period.

\section{Robustness checks}

To assess the robustness of the results obtained, we experimented with a number of alternative specifications. Firstly, we consider specifications that include two additional regressors that have been identified in the literature as potentially important correlates of financial development in Africa: population density and changes in terms of trade. The results of these regressions are presented in Table 5. The inclusion of the additional regressors does not change the basic finding that openness does not present a significant link with financial development.

Furthermore, we estimate a set of specifications analogous to the ones considered by Chinn and Ito (2006). These authors regress the first difference of a measure of financial development on past levels of financial development itself and lagged levels of other explanatory variables, as described in Equation 3. The lagged level of financial development is supposed to capture convergence effects such that a negative coefficient would indicate that more financially developed countries are expected to present slower growth in financial development measures. 


$$
\begin{aligned}
& \Delta F D_{i t}=\alpha_{i}+\rho_{i} F D_{i t-1}+\psi_{1 i} T O_{i t-1}+\psi_{2 i} F O_{i t-1}+\sum_{m=1}^{M} \beta_{m, i, t-1}+u_{i t} \\
& u_{i t}=\alpha_{i}+\lambda_{i} f_{t}+\varepsilon_{i t}
\end{aligned}
$$

In fact, the results presented in Annex E indicate that the autoregressive coefficient is negative and statistically significant, thus indicating that changes in financial development are negatively related to the past level of financial development. Once again the coefficient estimates for our measures of trade and financial openness are small and not statistically significant.

In addition, we also estimated regressions using more conventional dynamic panel estimators, namely the difference (Arellano-Bond) and system (Blundell-Bond) GMM estimators (Roodman, 2009). These estimators are subject to shortcomings highlighted in earlier sections of this paper, but they allow us to handle the potential endogeneity of some regressors by using lagged values of levels and first differences of these variables as instruments. The estimation results for specifications in levels and for specifications following Equation 3 (Chinn-Ito type regressions) are reported in Annex F.

Once again, the estimates for capital account openness are small and not statistically different from zero for all regressions. The impact of trade openness is more ambiguous with statistically significant effects obtained for Difference GMM regressions, but not for System GMM ones. Overall, despite the inclusion of time effects, the null of cross-sectional independence of the residuals is overwhelmingly rejected for these models, thus indicating that the estimates obtained are likely to be inconsistent.

Finally, we also considered models that include an alternative measure of institutional development, the indicator of the quality of bureaucracy from ICRG. The regression results, which are not reported here to save space, but are available from the authors upon request, once again fail to point to a robust statistically significant impact of trade and capital account openness on financial development in sub-Saharan African countries. 
Table 5. Robustness Checks: Additional Regressors

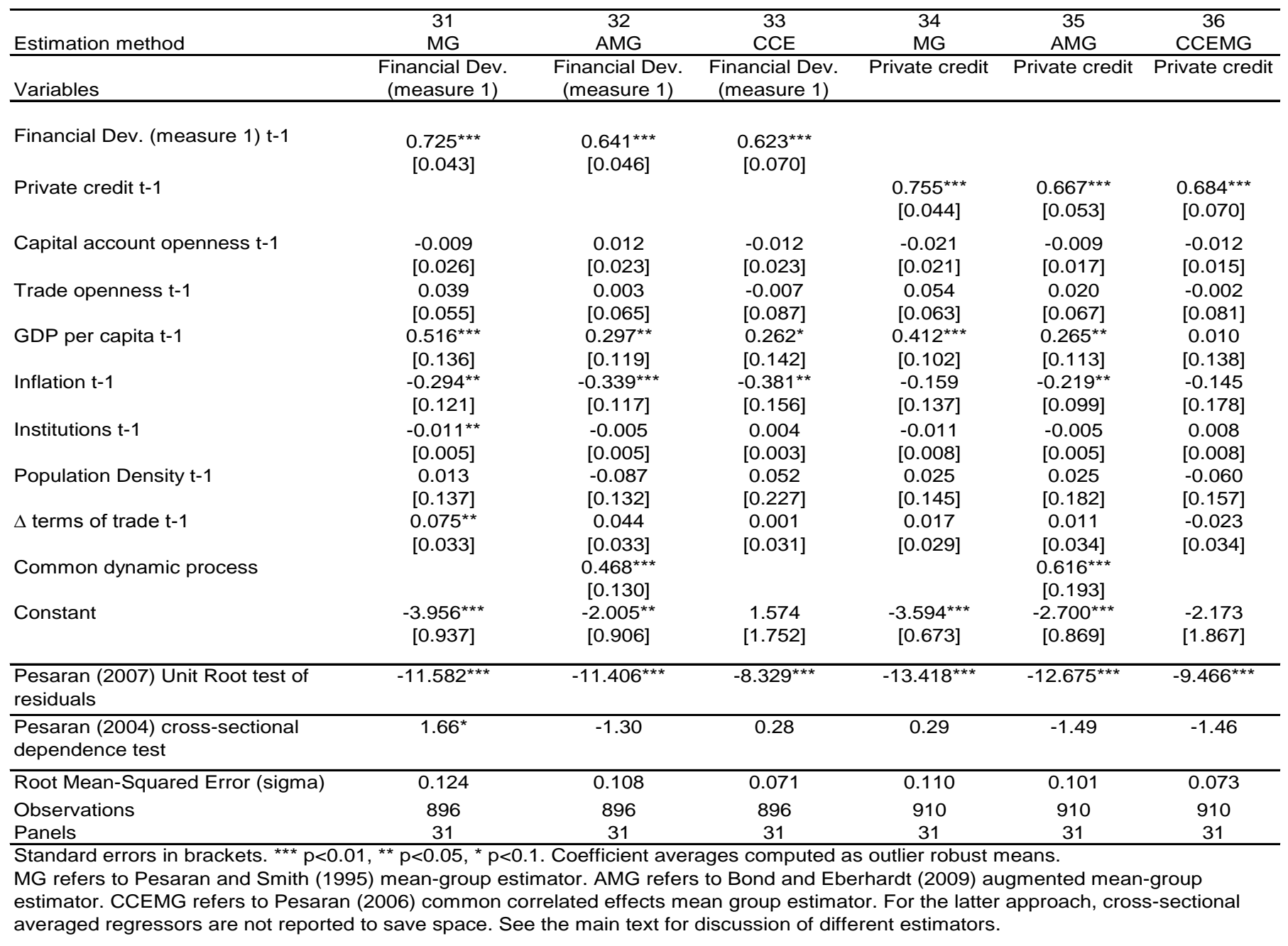

\section{Concluding Remarks}

The results presented in this paper for a panel of sub-Saharan African countries in general do not point to a robust direct link between trade and capital account openness and financial development, once we control for other factors such as GDP per capita and inflation. While it is possible to detect a positive and statistically significant effect for trade openness on financial development in a number of specifications (most notably for specifications restricted to the 1982-1995 period and/or for models considering a more restricted sample of countries), the links between financial development and capital account openness are not statistically significant in virtually all regressions estimated.

These results are not statement about whether openness is desirable or not per se, but they highlight the fact that is difficult to quantify direct gains in terms of further financial 
development for African countries in general terms. It is also important to bear in mind that given the panel techniques employed, the coefficients obtained are not necessarily valid for every country in the sample.

When we examine the cross-sectional association between the country-specific coefficients for capital account and trade openness and certain country characteristics, we find that there are some indications that trade openness is more important for financial development in countries with better institutional quality. However, it seems that the level of institutional quality does not ameliorate the impact of capital account openness on financial development in African economies.

These conclusions differ from the findings of a number of other authors for a broader sample of countries (for example, Baltagi, Demetriades and Law, 2009). Differences may partly be a reflection of different samples and econometric techniques used, but there might also be important economic and structural explanations that would prevent the realization of potential gains from further international integration. These impediments might include the presence of much weaker institutional frameworks in SSA relative to other regions, i.e., "threshold effects" due to the fact that the current level of institutions is so low that marginal improvements really do not matter that much for greater financial development, especially in the presence of significant distortions in domestic financial markets; and/or inadequate banking supervision.

In general, our results also suggest that policy makers should be cautious about their expectations regarding immediate gains in terms of financial deepening from greater trade and capital account openness. Such gains are likely to take time to materialize and are more likely to occur through indirect channels ("collateral benefits" in the words of Kose and others, 2009); in particular to the extent that greater integration leads to greater macroeconomic stability and/or higher growth. In fact, the evidence presented in the paper indicates that both GDP per capita and our proxy for macroeconomic stability are robustly linked to financial development in Africa.

That said, there are two recent phenomena that are likely to accelerate financial deepening in sub-Saharan Africa (Mlachila, Park and Yabara, 2012). First, the recent emergence of dynamic pan-African banks should increase competition and facilitate the spread of banking technology. There are now at least nine SSA-domiciled financial groups that operate in at least seven countries; Ecobank, for instance is now present in about 35 countries. Second, home-grown innovations in information and communications technologies have led to the widening of access to financial services to unbanked segments of the economy. Kenya has led the way with a mobile phone-based payments system, M-PESA, which has reached more than 80 percent of the adult population. 
Our conclusions might also have implications in terms of sequencing of financial sector reforms with the objective of promoting financial deepening. Given the stage of development of African economies, policies to promote macroeconomic stability, domestic financial liberalization, to increase competition in the banking system and to improve supervision should be prioritized relative to reforms that increase international financial integration. For instance, greater capital account openness in CFA countries has not conveyed to them any particular advantage in fostering financial development. 
Annex A: List of Countries Included in the Regressions

\begin{tabular}{ll}
\hline Angola & Lesotho \\
Benin & Madagascar \\
Botswana & Malawi \\
Burkina Faso & Mali \\
Burundi & Mauritius \\
Cameroon & Mozambique \\
Cape Verde & Niger \\
Central African Republic & Nigeria \\
Chad & Rwanda \\
Congo, Rep. & Senegal \\
Côte d'Ivoire & Sierra Leone \\
Ethiopia & South Africa \\
Gabon & Swaziland \\
Gambia, The & Tanzania \\
Ghana & Togo \\
Guinea-Bissau & Uganda \\
Kenya & Zambia \\
\hline
\end{tabular}


Annex B: Variables Definitions and Sources

\begin{tabular}{|c|c|c|}
\hline Variable & Description/Notes & Source \\
\hline $\begin{array}{l}\text { Comprehensive } \\
\text { financial } \\
\text { development } \\
\text { measure }\end{array}$ & $\begin{array}{l}\text { Constructed using a common factor for the } \\
\text { following indicators: liquid liabilities as a share of } \\
\text { GDP; credit to the private by deposit money banks, } \\
\text { credit to the private sector by banks and other } \\
\text { financial institutions, bank deposits, and financial } \\
\text { system deposits (all as a share of GDP). Some } \\
\text { missing years in the original data were interpolated } \\
\text { to avoid gaps in the panel. All original indicators } \\
\text { were transformed to logs. }\end{array}$ & $\begin{array}{l}\text { World Bank } \\
\text { Financial Structure } \\
\text { Database, Beck and } \\
\text { Demirgüç-Kunt } \\
\text { (2009). Authors' } \\
\text { calculations. }\end{array}$ \\
\hline $\begin{array}{l}\text { Private credit to } \\
\text { GDP }\end{array}$ & $\begin{array}{l}\text { Credit to the private sector by deposit money banks } \\
\text { in logs. } \ln \left(100^{*} p c r d b g d p\right) \text {. }\end{array}$ & $\begin{array}{l}\text { World Bank } \\
\text { Financial Structure } \\
\text { Database, Beck and } \\
\text { Demirgüç-Kunt } \\
\text { (2009). }\end{array}$ \\
\hline $\begin{array}{l}\text { Capital account } \\
\text { openness }\end{array}$ & $\begin{array}{l}\text { First principal component of four binary dummy } \\
\text { variables that codify de jure restrictions to the } \\
\text { financial account. Based on IMF's Annual report } \\
\text { on Exchange Arrangements and Exchange } \\
\text { Restrictions (AREAER). }\end{array}$ & $\begin{array}{l}\text { Chinn-Ito (2006), } \\
\text { updated in } 2010 .\end{array}$ \\
\hline GDP per capita & $\begin{array}{l}\text { Log of Real GDP per capita in PPP terms (Chain } \\
\text { Series), at } 2005 \text { constant prices. }\end{array}$ & $\begin{array}{l}\text { PWT 7, see Heston, } \\
\text { Summers and Aten } \\
(2011)\end{array}$ \\
\hline Inflation & Log of the CPI inflation rate, $\ln (1+$ inflation/100). & IMF WEO database. \\
\hline Trade openness & $\begin{array}{l}\text { Sum of Exports and Imports as a Share of GDP. } \\
\text { Included in logs in the regressions. }\end{array}$ & IMF WEO database. \\
\hline $\begin{array}{l}\text { Institutional } \\
\text { quality }\end{array}$ & $\begin{array}{l}\text { Constraints on executive power. Extent of } \\
\text { constraints on the decision-making powers of chief } \\
\text { executives, whether individuals or collectivities. } \\
\text { Values are expressed in } 7 \text { category scale, ranging } \\
\text { from unlimited authority to executive parity or } \\
\text { subordination. Values were set to zero during } \\
\text { transition periods, state failure and interruption. }\end{array}$ & $\begin{array}{l}\text { Polity IV Database, } \\
\text { Marshall, Jaggers, } \\
\text { and Gurr (2010). }\end{array}$ \\
\hline $\begin{array}{l}\text { Financial Reforms } \\
\text { Index }\end{array}$ & $\begin{array}{l}\text { Aggregate normalized index coding several } \\
\text { financial reforms, including removal of credit } \\
\text { controls, entry barriers, privatization, among others. }\end{array}$ & $\begin{array}{l}\text { Abiad, Detragiache, } \\
\text { and Tressel (2010). }\end{array}$ \\
\hline Population density & In $\mathrm{km}$ squared. Included in logs in the regressions. & $\begin{array}{l}\text { World Bank's WDI } \\
\text { database. }\end{array}$ \\
\hline Terms of Trade & $\begin{array}{l}\text { Index for goods and services base year is } 2005 \text {. } \\
\text { Included in logs in the regressions. }\end{array}$ & IMF WEO database \\
\hline $\begin{array}{l}\text { Quality of } \\
\text { bureaucracy } \\
\text { indicator }\end{array}$ & $\begin{array}{l}\text { Index varying from } 0 \text { to } 100 \text {. Included in logs in the } \\
\text { regressions. }\end{array}$ & $\begin{array}{l}\text { International Country } \\
\text { Risk Guide. }\end{array}$ \\
\hline
\end{tabular}




\section{Annex C: Descriptive Statistics for Selected Variables}

\begin{tabular}{|c|c|c|c|c|c|c|}
\hline Variable & & Mean & Std. Dev. & Min & Max & Observations \\
\hline Log Private Credit to GDP & $\begin{array}{l}\text { overall } \\
\text { between } \\
\text { within }\end{array}$ & 2.39 & $\begin{array}{l}0.85 \\
0.75 \\
0.50\end{array}$ & $\begin{array}{l}-0.92 \\
-0.04 \\
0.26\end{array}$ & $\begin{array}{l}4.47 \\
3.98 \\
4.33\end{array}$ & $\begin{array}{cc}\mathrm{N}= & 1155 \\
\mathrm{n}= & 36 \\
\text { T-bar }= & 32.0833\end{array}$ \\
\hline Financial Dev. Measure 1 & $\begin{array}{l}\text { overall } \\
\text { between } \\
\text { within }\end{array}$ & 0.00 & $\begin{array}{l}1.00 \\
0.89 \\
0.55\end{array}$ & $\begin{array}{l}-3.88 \\
-2.73 \\
-3.14\end{array}$ & $\begin{array}{l}2.46 \\
1.92 \\
2.39\end{array}$ & $\begin{array}{cc}\mathrm{N}= & 1139 \\
\mathrm{n}= & 36 \\
\text { T-bar }= & 31.6389\end{array}$ \\
\hline Capital Account Index & $\begin{array}{l}\text { overall } \\
\text { between } \\
\text { within }\end{array}$ & -0.73 & $\begin{array}{l}0.95 \\
0.61 \\
0.76\end{array}$ & $\begin{array}{l}-1.86 \\
-1.41 \\
-3.16\end{array}$ & $\begin{array}{l}2.46 \\
1.58 \\
1.90\end{array}$ & $\begin{array}{cc}\mathrm{N}= & 1319 \\
\mathrm{n}= & 36 \\
\text { T-bar }= & 36.6389\end{array}$ \\
\hline Log GDP per capita & $\begin{array}{l}\text { overall } \\
\text { between } \\
\text { within }\end{array}$ & 7.10 & $\begin{array}{l}0.89 \\
0.87 \\
0.26\end{array}$ & $\begin{array}{l}4.76 \\
5.96 \\
5.69\end{array}$ & $\begin{array}{c}10.19 \\
9.41 \\
7.99\end{array}$ & $\begin{array}{cc}\mathrm{N}= & 1440 \\
\mathrm{n}= & 36 \\
\mathrm{~T}= & 40\end{array}$ \\
\hline Log Inflation & $\begin{array}{l}\text { overall } \\
\text { between } \\
\text { within }\end{array}$ & 0.15 & $\begin{array}{l}0.32 \\
0.17 \\
0.27\end{array}$ & $\begin{array}{c}-0.42 \\
0.04 \\
-0.68\end{array}$ & $\begin{array}{l}5.48 \\
0.87 \\
4.75\end{array}$ & $\begin{array}{cc}\mathrm{N}= & 1440 \\
\mathrm{n}= & 36 \\
\mathrm{~T}= & 40\end{array}$ \\
\hline Log Tade Openness & $\begin{array}{l}\text { overall } \\
\text { between } \\
\text { within }\end{array}$ & 4.05 & $\begin{array}{l}0.60 \\
0.52 \\
0.32\end{array}$ & $\begin{array}{l}1.43 \\
3.09 \\
2.09\end{array}$ & $\begin{array}{l}5.54 \\
5.04 \\
5.11\end{array}$ & $\begin{array}{cc}\mathrm{N}= & 1430 \\
\mathrm{n}= & 36 \\
\mathrm{~T}-\mathrm{bar}= & 39.7222\end{array}$ \\
\hline Constraints on the Exec. & $\begin{array}{l}\text { overall } \\
\text { between } \\
\text { within }\end{array}$ & 2.93 & $\begin{array}{l}2.05 \\
1.46 \\
1.46\end{array}$ & $\begin{array}{r}0.00 \\
1.05 \\
-3.72\end{array}$ & $\begin{array}{l}7.00 \\
7.00 \\
7.31\end{array}$ & $\begin{array}{cc}\mathrm{N}= & 1381 \\
\mathrm{n}= & 35 \\
\text { T-bar }= & 39.4571\end{array}$ \\
\hline Log Terms of Trade & $\begin{array}{l}\text { overall } \\
\text { between } \\
\text { within }\end{array}$ & 4.79 & $\begin{array}{l}0.69 \\
0.47 \\
0.50\end{array}$ & $\begin{array}{l}2.73 \\
3.97 \\
3.18\end{array}$ & $\begin{array}{l}7.54 \\
6.43 \\
6.97\end{array}$ & $\begin{array}{cc}\mathrm{N}= & 1275 \\
\mathrm{n}= & 36 \\
\mathrm{~T}-\mathrm{bar}= & 35.4167\end{array}$ \\
\hline Log Population Density & $\begin{array}{l}\text { overall } \\
\text { between } \\
\text { within }\end{array}$ & 3.45 & $\begin{array}{l}1.29 \\
1.27 \\
0.31\end{array}$ & $\begin{array}{l}0.20 \\
0.82 \\
2.70\end{array}$ & $\begin{array}{l}6.44 \\
6.25 \\
4.09\end{array}$ & $\begin{array}{cc}\mathrm{N}= & 1440 \\
\mathrm{n}= & 36 \\
\mathrm{~T}= & 40\end{array}$ \\
\hline Log of quality of bureaucracy & $\begin{array}{l}\text { overall } \\
\text { between } \\
\text { within }\end{array}$ & 4.02 & $\begin{array}{l}0.20 \\
0.14 \\
0.14\end{array}$ & $\begin{array}{l}3.24 \\
3.68 \\
3.36\end{array}$ & $\begin{array}{l}4.44 \\
4.34 \\
4.43\end{array}$ & $\begin{array}{cc}\mathrm{N}= & 649 \\
\mathrm{n}= & 26 \\
\text { T-bar } & =24.9615\end{array}$ \\
\hline
\end{tabular}


Annex D: Panel Unit Root Tests

\begin{tabular}{|c|c|c|c|c|c|c|c|}
\hline & $\begin{array}{c}\text { Financial sector dev. } \\
\text { measure } 1\end{array}$ & Private credit & GDP per capita & Inflation & Trade openness & $\begin{array}{c}\text { Capital account } \\
\text { openness }\end{array}$ & $\begin{array}{l}\text { Constraints on the } \\
\text { Executive }\end{array}$ \\
\hline \multicolumn{8}{|c|}{$\begin{array}{l}\text { Maddala and Wu (1999) test } \\
\text { without trend } \\
\text { One lag }\end{array}$} \\
\hline Chi-squared statistic & 62.06 & 72.57 & 67.03 & 251.81 & 128.02 & 95.61 & 137.88 \\
\hline \multicolumn{8}{|l|}{ Two lags } \\
\hline Chi-squared statistic & 60.81 & 69.54 & 53.47 & 142.35 & 98.22 & 80.61 & 82.04 \\
\hline$p$-value & 0.72 & 0.43 & 0.90 & 0.00 & 0.01 & 0.14 & 0.12 \\
\hline \multicolumn{8}{|l|}{$\begin{array}{l}\text { with trend } \\
\text { One lag }\end{array}$} \\
\hline Chi-squared statistic & 55.17 & 66.38 & 66.91 & 237.86 & 124.91 & 108.80 & 122.85 \\
\hline $\begin{array}{l}\text { p-value } \\
\text { Two lags }\end{array}$ & 0.87 & 0.53 & 0.52 & 0.00 & 0.00 & 0.00 & 0.00 \\
\hline Chi-squared statistic & 55.78 & 69.45 & 59.26 & 135.32 & 94.23 & 98.71 & 70.43 \\
\hline$p$-value & 0.86 & 0.43 & 0.77 & 0.00 & 0.02 & 0.01 & 0.40 \\
\hline \multicolumn{4}{|c|}{$\begin{array}{l}\text { Ho: series is I(1) for all panel members; H1: series is stationary for at least one } \\
\text { panel member }\end{array}$} & \multicolumn{2}{|c|}{ Number of panels $=34$} & \multicolumn{2}{|c|}{ Number of observations $=1,065$} \\
\hline \multicolumn{8}{|l|}{$\begin{array}{l}\text { Pesaran (2007) test } \\
\text { without trend } \\
\text { One lag }\end{array}$} \\
\hline Zt-bar statistic & -0.21 & 0.02 & 1.34 & -8.30 & -3.26 & -0.84 & 0.33 \\
\hline $\begin{array}{l}\mathrm{p} \text {-value } \\
\text { Two lags }\end{array}$ & 0.42 & 0.51 & 0.91 & 0.00 & 0.00 & 0.20 & 0.63 \\
\hline Zt-bar statistic & 0.75 & 1.54 & 2.95 & -0.13 & -1.82 & -1.95 & 2.95 \\
\hline$p$-value & 0.77 & 0.94 & 1.00 & 0.45 & 0.03 & 0.03 & 1.00 \\
\hline \multicolumn{8}{|l|}{$\begin{array}{l}\text { with trend } \\
\text { One lag }\end{array}$} \\
\hline Zt-bar statistic & 0.00 & 0.77 & -3.35 & -9.39 & -3.93 & 0.68 & 1.40 \\
\hline $\begin{array}{l}\text { p-value } \\
\text { Two lags }\end{array}$ & 0.50 & 0.78 & 0.00 & 0.00 & 0.00 & 0.75 & 0.92 \\
\hline Zt-bar statistic & 0.60 & 2.29 & -0.64 & -0.63 & -2.44 & 0.14 & 4.22 \\
\hline $\mathrm{p}$-value & 0.72 & 0.99 & 0.26 & 0.27 & 0.01 & 0.55 & 1.00 \\
\hline
\end{tabular}

Maddala and Wu (1999) test allows for cross-sectional heterogeneity, but assumes cross-sectional independence. Pesaran (2007) test allows for cross-sectional heterogeneity and assumes cross-sectional dependence in the form of one unobserved common factor. 
Annex E: Robustness Checks: Chinn-Ito (2006) regressions

\begin{tabular}{|c|c|c|c|c|c|c|}
\hline Estimation method & $\begin{array}{c}1 \\
M G\end{array}$ & $\begin{array}{c}2 \\
\text { AMG }\end{array}$ & $\begin{array}{c}3 \\
\mathrm{CCE}\end{array}$ & $\begin{array}{c}4 \\
M G\end{array}$ & $\begin{array}{c}5 \\
\mathrm{AMG}\end{array}$ & $\begin{array}{c}6 \\
\text { CCEMG }\end{array}$ \\
\hline Variables & $\begin{array}{c}\Delta \text { Financial Dev. } \\
\text { (measure } 1)\end{array}$ & $\begin{array}{c}\Delta \text { Financial Dev. } \\
\text { (measure 1) }\end{array}$ & $\begin{array}{c}\Delta \text { Financial Dev. } \\
\text { (measure 1) }\end{array}$ & $\Delta$ Private credit & $\Delta$ Private credit & $\Delta$ Private credit \\
\hline Financial Dev. (measure 1) t-1 & $\begin{array}{l}-0.190^{\star * *} \\
{[0.029]}\end{array}$ & $\begin{array}{l}-0.273^{\star \star \star} \\
{[0.038]}\end{array}$ & $\begin{array}{l}-0.402^{* * *} \\
{[0.051]}\end{array}$ & & & \\
\hline Private credit $\mathrm{t}-1$ & & & & $\begin{array}{l}-0.157^{\star \star \star} \\
{[0.027]}\end{array}$ & $\begin{array}{l}-0.203^{\star \star \star} \\
{[0.034]}\end{array}$ & $\begin{array}{l}-0.297^{\star * *} \\
{[0.043]}\end{array}$ \\
\hline Capital account openness t- 1 & $\begin{array}{l}-0.031 \\
{[0.021]}\end{array}$ & $\begin{array}{l}-0.010 \\
{[0.021]}\end{array}$ & $\begin{array}{l}-0.024 \\
{[0.022]}\end{array}$ & $\begin{array}{l}-0.027 \\
{[0.022]}\end{array}$ & $\begin{array}{c}0.004 \\
{[0.018]}\end{array}$ & $\begin{array}{l}-0.004 \\
{[0.015]}\end{array}$ \\
\hline Trade openness $\mathrm{t}-1$ & $\begin{array}{c}0.050 \\
{[0.053]}\end{array}$ & $\begin{array}{c}0.023 \\
{[0.052]}\end{array}$ & $\begin{array}{c}0.032 \\
{[0.065]}\end{array}$ & $\begin{array}{c}0.082 \\
{[0.061]}\end{array}$ & $\begin{array}{c}0.063 \\
{[0.056]}\end{array}$ & $\begin{array}{c}0.059 \\
{[0.085]}\end{array}$ \\
\hline GDP per capita t-1 & $\begin{array}{l}0.399^{\star \star *} \\
{[0.112]}\end{array}$ & $\begin{array}{l}0.245^{\star \star} \\
{[0.104]}\end{array}$ & $\begin{array}{l}0.316^{\star *} \\
{[0.157]}\end{array}$ & $\begin{array}{l}0.327^{\star \star \star} \\
{[0.098]}\end{array}$ & $\begin{array}{l}0.264^{\star \star} \\
{[0.104]}\end{array}$ & $\begin{array}{l}0.278^{\star} \\
{[0.148]}\end{array}$ \\
\hline Inflation $\mathrm{t}-1$ & $\begin{array}{l}-0.267^{\star * *} \\
{[0.099]}\end{array}$ & $\begin{array}{l}-0.295^{\star \star \star} \\
{[0.110]}\end{array}$ & $\begin{array}{l}-0.284^{* *} \\
{[0.129]}\end{array}$ & $\begin{array}{l}-0.211^{* *} \\
{[0.105]}\end{array}$ & $\begin{array}{l}-0.208^{\star *} \\
{[0.099]}\end{array}$ & $\begin{array}{l}-0.214 \\
{[0.143]}\end{array}$ \\
\hline Institutions t-1 & $\begin{array}{c}0.002 \\
{[0.007]}\end{array}$ & $\begin{array}{l}-0.006 \\
{[0.006]}\end{array}$ & $\begin{array}{l}-0.000 \\
{[0.009]}\end{array}$ & $\begin{array}{l}-0.004 \\
{[0.008]}\end{array}$ & $\begin{array}{l}-0.002 \\
{[0.006]}\end{array}$ & $\begin{array}{c}0.004 \\
{[0.011]}\end{array}$ \\
\hline Common dynamic process & & $\begin{array}{l}0.515^{\star \star \star} \\
{[0.118]}\end{array}$ & & & $\begin{array}{l}0.492^{\star * *} \\
{[0.141]}\end{array}$ & \\
\hline Constant & $\begin{array}{c}-3.066^{\star * *} \\
{[0.752]}\end{array}$ & $\begin{array}{l}-1.334 \\
{[0.898]}\end{array}$ & $\begin{array}{l}-1.703 \\
{[1.556]}\end{array}$ & $\begin{array}{c}-2.310^{\star \star *} \\
{[0.660]}\end{array}$ & $\begin{array}{l}-1.224 \\
{[0.770]}\end{array}$ & $\begin{array}{l}-1.241 \\
{[1.780]}\end{array}$ \\
\hline $\begin{array}{l}\text { Pesaran (2007) Unit Root test of } \\
\text { residuals }\end{array}$ & $-11.834^{\star \star \star}$ & $-12.064^{\star \star \star}$ & $-16.219^{\star \star \star}$ & $-12.521^{\star \star \star}$ & $-12.716^{\star \star \star}$ & $-15.537^{\star \star \star}$ \\
\hline $\begin{array}{l}\text { Pesaran (2004) cross-sectional } \\
\text { dependence test }\end{array}$ & $3.13^{* \star \star}$ & -0.30 & -0.64 & 1.02 & -1.17 & -0.12 \\
\hline Root Mean-Squared Error (sigma) & 0.142 & 0.130 & 0.090 & 0.130 & 0.121 & 0.087 \\
\hline $\begin{array}{l}\text { Observations } \\
\text { Panels }\end{array}$ & $\begin{array}{c}1,031 \\
34 \\
\end{array}$ & $\begin{array}{c}1,031 \\
34 \\
\end{array}$ & $\begin{array}{c}1,031 \\
34 \\
\end{array}$ & $\begin{array}{c}1,045 \\
34 \\
\end{array}$ & $\begin{array}{c}1,045 \\
34 \\
\end{array}$ & $\begin{array}{c}1,045 \\
34 \\
\end{array}$ \\
\hline
\end{tabular}

Standard errors in brackets. ${ }^{* * *} p<0.01,{ }^{* *} p<0.05,{ }^{*} p<0.1$. Coefficient averages computed as outlier robust means.

MG refers to Pesaran and Smith (1995) mean-group estimator. AMG refers to Bond and Eberhardt (2009) augmented mean-group estimator.

CCEMG refers to Pesaran (2006) common correlated effects mean group estimator. For the latter approach, cross-sectional averaged

regressors are not reported to save space. See the main text for discussion of different estimators. 
Annex F: GMM Estimators

\begin{tabular}{|c|c|c|c|c|c|c|c|c|}
\hline Estimation method & $\begin{array}{c}1 \\
\text { Difference GMM } \\
\text { Financial Dey }\end{array}$ & $\begin{array}{c}2 \\
\text { System GMM } \\
\text { Financial Dey }\end{array}$ & $\begin{array}{c}3 \\
\text { Difference GMM } \\
\text { Private credit }\end{array}$ & $\begin{array}{c}4 \\
\text { System GMM } \\
\text { Private credit }\end{array}$ & $\begin{array}{c}5 \\
\text { Difference GMM } \\
\Delta \text { Financial Dey }\end{array}$ & $\begin{array}{c}6 \\
\text { System GMM } \\
\text { Financial Dey }\end{array}$ & $\begin{array}{c}7 \\
\text { Difference GMM } \\
\text { Private credit }\end{array}$ & $\begin{array}{c}8 \\
\text { System GMM } \\
\text { Private credit }\end{array}$ \\
\hline Variables & (measure 1) & (measure 1) & & & (measure 1) & (measure 1) & & \\
\hline Financial Dev. (measure 1) t-1 & $\begin{array}{l}0.891^{\star \star \star} \\
{[0.029]}\end{array}$ & $\begin{array}{l}0.932^{\star \star \star} \\
{[0.026]}\end{array}$ & & & $\begin{array}{l}-0.109^{\star \star \star} \\
{[0.029]}\end{array}$ & $\begin{array}{c}-0.068^{\star \star} \\
{[0.026]}\end{array}$ & & \\
\hline Private credit $\mathrm{t}-1$ & & & $\begin{array}{l}0.894^{* * *} \\
{[0.036]}\end{array}$ & $\begin{array}{c}0.934^{\star * *} \\
{[0.023]}\end{array}$ & & & $\begin{array}{l}-0.106^{\star * *} \\
{[0.036]}\end{array}$ & $\begin{array}{c}-0.066^{\star * *} \\
{[0.023]}\end{array}$ \\
\hline Capital account openness $t$ & $\begin{array}{c}0.004 \\
{[0.015]}\end{array}$ & $\begin{array}{c}0.002 \\
{[0.009]}\end{array}$ & $\begin{array}{l}-0.009 \\
{[0.017]}\end{array}$ & $\begin{array}{l}-0.009 \\
{[0.008]}\end{array}$ & $\begin{array}{c}0.004 \\
{[0.015]}\end{array}$ & $\begin{array}{c}0.002 \\
{[0.009]}\end{array}$ & $\begin{array}{l}-0.009 \\
{[0.017]}\end{array}$ & $\begin{array}{c}-0.009 \\
{[0.008]}\end{array}$ \\
\hline Trade openness $t$ & $\begin{array}{c}0.150^{\star \star *} \\
{[0.049]}\end{array}$ & $\begin{array}{c}0.036 \\
{[0.044]}\end{array}$ & $\begin{array}{c}0.172^{\star * \star} \\
{[0.045]}\end{array}$ & $\begin{array}{c}0.051 \\
{[0.044]}\end{array}$ & $\begin{array}{c}0.150^{\star \star \star} \\
{[0.049]}\end{array}$ & $\begin{array}{c}0.036 \\
{[0.044]}\end{array}$ & $\begin{array}{c}0.172^{\star \star \star} \\
{[0.045]}\end{array}$ & $\begin{array}{c}0.051 \\
{[0.044]}\end{array}$ \\
\hline GDP per capita $t$ & $\begin{array}{c}0.100 \\
{[0.092]}\end{array}$ & $\begin{array}{c}0.039 \\
{[0.034]}\end{array}$ & $\begin{array}{c}0.145 \\
{[0.090]}\end{array}$ & $\begin{array}{c}0.054 \\
{[0.040]}\end{array}$ & $\begin{array}{c}0.100 \\
{[0.092]}\end{array}$ & $\begin{array}{c}0.039 \\
{[0.034]}\end{array}$ & $\begin{array}{c}0.145 \\
{[0.090]}\end{array}$ & $\begin{array}{c}0.054 \\
{[0.040]}\end{array}$ \\
\hline Inflation t & $\begin{array}{l}-0.057 \\
{[0.108]}\end{array}$ & $\begin{array}{l}-0.056 \\
{[0.083]}\end{array}$ & $\begin{array}{l}-0.057 \\
{[0.077]}\end{array}$ & $\begin{array}{l}-0.045 \\
{[0.053]}\end{array}$ & $\begin{array}{l}-0.057 \\
{[0.108]}\end{array}$ & $\begin{array}{l}-0.056 \\
{[0.083]}\end{array}$ & $\begin{array}{l}-0.057 \\
{[0.077]}\end{array}$ & $\begin{array}{l}-0.045 \\
{[0.053]}\end{array}$ \\
\hline Institutions t & $\begin{array}{l}-0.000 \\
{[0.009]}\end{array}$ & $\begin{array}{c}0.006 \\
{[0.008]}\end{array}$ & $\begin{array}{l}-0.011 \\
{[0.011]}\end{array}$ & $\begin{array}{l}-0.004 \\
{[0.007]}\end{array}$ & $\begin{array}{r}-0.000 \\
{[0.009]}\end{array}$ & $\begin{array}{c}0.006 \\
{[0.008]}\end{array}$ & $\begin{array}{l}-0.011 \\
{[0.011]}\end{array}$ & $\begin{array}{l}-0.004 \\
{[0.007]}\end{array}$ \\
\hline Constant & & $\begin{array}{l}-0.252 \\
{[0.185]}\end{array}$ & & $\begin{array}{l}-0.288 \\
{[0.206]}\end{array}$ & & $\begin{array}{l}-0.252 \\
{[0.185]}\end{array}$ & & $\begin{array}{l}-0.288 \\
{[0.206]}\end{array}$ \\
\hline $\begin{array}{l}\text { Sargan test for overidentified } \\
\text { restrictions }\end{array}$ & $296.51^{\star \star \star}$ & $320.22^{\star \star \star}$ & $258.44^{\star \star}$ & $295.80^{\star \star \star}$ & $295.51^{\star \star \star}$ & $320.22^{\star \star \star}$ & $258.44^{\star \star}$ & $295.80^{\star \star \star}$ \\
\hline $\begin{array}{l}\text { Pesaran (2004) cross-sectional } \\
\text { dependence test }\end{array}$ & $-2.08^{\star \star}$ & $-1.92^{\star \star}$ & $-3.21^{\star \star \star}$ & $-3.01^{\star \star \star}$ & $-2.08^{\star \star}$ & $-1.92^{\star \star}$ & $-3.21^{\star \star \star}$ & $-3.01^{* \star *}$ \\
\hline Time effects & Yes & Yes & Yes & Yes & Yes & Yes & Yes & Yes \\
\hline Observations & 1,004 & 1,039 & 1,019 & 1,054 & 1,004 & 1,039 & 1,019 & 1,054 \\
\hline Panels & 35 & 35 & 35 & 35 & 35 & 35 & 35 & 35 \\
\hline
\end{tabular}

Standard errors in brackets. ${ }^{\star \star \star} p<0.01,{ }^{\star \star} p<0.05,{ }^{*} p<0.1$. Heterocedasticity and autocorrelation robust standard errors clustered by country. Coefficients on time dummies not reported to save space. 


\section{References}

Abiad, A., E. Detragiache, and T. Tressel, 2010, "A New Database of Financial Reforms" IMF Staff Papers, Vol. 57, Issue 2, pp. 281-302.

Acemoglu, D., and S. Johnson, 2005, “Unbundling Institutions”, Journal of Political Economy, Vol. 113, No.5, pp. 949-95.

Allen, F., E. Carletti, R. Cull, J. Qian, L. Senbet, and P. Valenzuela, 2012, “ Resolving the African Financial Development Gap: Cross-Country Comparisons and a WithinCountry Study of Kenya,” NBER Working Paper No. 18013.

Baltagi, B.H., P.O. Demetriades, and S.H. Law, 2009, "Financial Development and Openness: Evidence from Panel Data," Journal of Development Economics, Vol. 84 No. 2, pp. 285-96.

Beck, T., and P. Honohan, 2007, Making Finance Work for Africa, (Washington: World Bank).

Beck, T., and A. Demirgüç-Kunt, 2009, "Financial Institutions and Markets Across Countries and Over Time: Data and Analysis," World Bank Policy Research Working Paper No. 4943, (Washington: World Bank).

Bond, S. and M. Eberhardt, 2009, "Cross-section Dependence in Nonstationary Panel Models: a Novel Estimator" Paper prepared for the Nordic Econometrics Meeting in Lund, Sweden, 29-31 October.

Boyd, J.H., R. Levine, and B.D. Smith, 2001, "The Impact of Inflation on Financial Sector Performance," Journal of Monetary Economics, Vol. 47, pp. 221-48.

Chinn, M. D., and H. Ito, 2006, "What Matters for Financial Development? Capital Controls, Institutions, and Interactions”, Journal of Development Economics, Vol. 81, No. 1, pp. 163-92.

Eberhardt, M., 2012, "Estimating Panel Time-series Models with Heterogeneous Slopes," Stata Journal, Vol. 12, No. 1, pp. 61-71.

Eberhardt, M., and F. Teal, 2011, "Econometrics for Grumblers: A New Look at the Literature on Cross-country Growth Empirics," Journal of Economic Surveys, Vol. 25, No.1, pp. 109-155.

Eberhardt, M., and F. Teal, 2013, "Structural Change and Cross-Country Growth Empirics" World Bank Economic Review, 27(2), 229-271.

Gries, T., M. Kraft, , and D. Meierrieks, 2009, "Linkages between Financial Deepening, Trade Openness, and Economic Development: Causality Evidence from Sub-Saharan Africa," World Development, Vol. 37, No. 12, pp. 1849-60.

Henry, P.B., 2007, “Capital Account Liberalization: Theory, Evidence, and Speculation," Journal of Economic Literature, Vol. XLV, pp. 887-935. 
Heston, A., R. Summers, and B. Aten, 2011, "Penn World Table Version 7.0", Center for International Comparisons of Production, Income and Prices at the University of Pennsylvania, June.

Kapetanios, G., M.H. Pesaran, and T.Yamagata, 2011, "Panels with nonstationary multifactor error structures", Journal of Econometrics, Vol. 160, 326-348.

Klein, M., and G. Olivei, 2008, "Capital Account Liberalization, Financial Depth, and Economic Growth", Journal of International Money and Finance, Vol. 27(6), pages 861-875, October.

Kose, M.A., E. Prasad, K. Rogoff, and S. Wei, 2009, "Financial Globalization: A Reappraisal", IMF Staff Papers, Vol. 56, No.1, 8-62.

Lane, P. R., and G.M. Milesi-Ferreti, 2006, "The External Wealth of Nations Mark II: Revised and Extended Estimates of Foreign Assets and Liabilities, 1970-2004", IMF Working Paper 06/69 (Washington: International Monetary Fund).

Levine, R., 2001, "International Financial Liberalization and Economic Growth", Review of International Economics, 9(4), pp 688-701.

Maddala, G.S., and S. Wu, 1999 "A Comparative Study of Unit Root Tests with Panel Data and a New Simple Test" Oxford Bulletin of Economics and Statistics, Vol. 61, 631652.

Marshall, M. G., K Jaggers,, and T. R Gurr, 2010 "Polity IV Project: Political Regime Characteristics and Transitions, 1800-2010" Center for Systemic Peace.

Mishkin, F., 2009, “Why We Shouldn't Turn Our Backs on Financial Globalization”, IMF Staff Papers, Vol.56, No.1, pp.139-170.

Mlachila, M., S. Park, and M. Yabara, 2012, "Banking in Sub-Saharan Africa: the Macroeconomic Context" in Banking in Sub-Saharan Africa: Challenges and Opportunities (Luxembourg: European Investment Bank).

Pesaran, M.H., and R. Smith, 1995, "Estimating Long-Run Relationships from Dynamic Heterogeneous Panels", Journal of Econometrics, Vol. 68, pp. 79-113.

Pesaran, H., 2004, "General Diagnostic Tests for Cross Section Dependence in Panels", Cambridge Working Papers in Economics, 0435, University of Cambridge.

Pesaran, M.H. 2006, "Estimation and Inference in Large Heterogeneous Panels with Multifactor Error Structure", Econometrica, Vol. 64, No. 4, pp. 967-1012.

Pesaran, M.H., 2007, "A Simple Panel Unit Root Test in the Presence of Cross-Section Dependence" Journal of Applied Econometrics, Vol. 22, No. 2, pp. 265-312.

Quinn, D., M. Schindler, and A.M. Toyoda, 2011, "Assessing Measures of Financial Openness and Integration" IMF Economic Review, Vol. 59, No. 3, pp. 488-522. 
Rajan, R.G., and L. Zingales, 2003, "The Great Reversals: The Politics of Financial Development in the Twentieth Century" Journal of Financial Economics, Vol. 69, pp. 5-50

Roodman, D., 2009, "How to Do xtabond2: An Introduction to "Difference" and "System" GMM in Stata". Stata Journal, Vol. 9, No. 1, pp. 86-136.

Sachs, J. D., and A. Warner, 1995, "Economic Reform and the Process of Global Integration”, Brookings Papers on Economic Activity, No. 1 pp.1-118.

Singh, R., K. Kpodar, and D. Ghura, 2009, "Financial Deeping in the CFA Franc Zone: The Role of Institutions” IMF Working Paper 09/113, May, (Washington: International Monetary Fund).

Svaleryd, H., and J. Vlachos, 2002, "Markets for Risk and Openness to Trade: How Are They Related?”, Journal of International Economics, Vol. 57, pp. 369-395

Svaleryd, H., and J. Vlachos, 2005, "Financial Markets, The Pattern of Industrial Specialization and Comparative Advantage: Evidence from OECD countries", European Economic Review, Vol. 49, pp. 113-144

Tressel, T., and E. Detragiache, 2008, "Do Financial Sector Reforms Lead to Financial Development?" Evidence from a New Dataset” IMF Working Paper 08/265, December, (Washington: International Monetary Fund). 